\title{
Synthetic Access to Hydrophilic Tetramate Derivatives of Cysteine
}

Ruirui Zhang, ${ }^{\dagger}$ Xiang Li, ${ }^{\dagger,+}$ Miroslav Genov, ${ }^{\ddagger}$ Alexander Pretsch, ${ }^{\ddagger}$ Dagmar Pretsch,${ }^{\ddagger}$ and Mark G. Moloney*,†,\#

${ }^{\dagger}$ The Department of Chemistry, Chemistry Research Laboratory, University of Oxford, 12 Mansfield Road, Oxford. OX1 3TA

${ }^{+}$Department of Pharmaceutical Engineering, China Pharmaceutical University, Nanjing, 211198, P. R. China.

\#Oxford Suzhou Centre for Advanced Research, Building A, 388 Ruo Shui Road, Suzhou Industrial Park, Jiangsu, 215123, P.R. China.

†Oxford Antibiotic Group, The Oxford Science Park, Magdalen Centre, Oxford OX4 4GA, UK.

mark.moloney@chem.ox.ac.uk

\begin{abstract}
The synthesis, structural and antibacterial evaluation of bicyclic tetramate derivatives of cysteine rendered hydrophilic with pendant heterocyclic substituents is reported; effective synthetic protocols and antibacterial activity for a small library of polar derivatives was found, and direct evidence for strong metal chelation in these systems was obtained. A computational study has developed a detailed understanding of the controlling factors of the key Dieckmann cyclisation step.
\end{abstract}

\section{Introduction}

The emergence of antimicrobial resistance (AMR) leading to the loss of efficacy of clinically relevant antibiotics, particularly in the ESKAPE pathogens (Enterococcus faecium, Staphylococcus aureus, Klebsiella pneumoniae, Acinetobacter baumanii, Pseudomonas aeruginosa, and Enterobacter species), ${ }^{1}$ has clearly demonstrated that new antibacterial small molecule entities are urgently needed. ${ }^{2-4}$ Antibacterial natural products have traditionally provided a valuable and 
accessible start point for drug discovery, ${ }^{5-9}$ and our interest in this area has focussed on tetramatecontaining systems, since such natural products may exhibit wide ranging antibacterial activity coupled with low levels of toxicity. ${ }^{10-13}$ New synthetic routes to these compounds continue to be developed. ${ }^{10,14-17}$ We have previously reported detailed investigations of bicyclic tetramates which have both demonstrated their ease of synthesis and potent antibacterial activity, at least for Gram positive systems, ${ }^{18}$ and more recently in particular that cysteine-derived tetramate analogues with functionalisation at C-2 and C-7 are highly effective (Figure 1$) ;{ }^{19,}{ }^{20}$ however, one key limitation of this and much of our earlier work has been the reliance on a $t$-butyl ring substituent which has been required for good chemical stability of intermediates, since only limited alternatives appear to be tolerated, and especially for $\mathrm{O}, \mathrm{N}$-systems. ${ }^{18}$ However, the better stability of $S, N$-systems offered the possibility to move away from such highly hydrophobic substituents, but even in these cases, in vitro activities diminished when tested in presence of blood, suggesting that plasma protein binding might be impacting upon free blood concentration and hence potency. ${ }^{19}$ Hansch noted in 1987 that "Without convincing evidence to the contrary, drugs should be made as hydrophilic as possible without loss of efficacy." ${ }^{21}$ With this in mind, we sought to increase compound polarity by incorporation of heterocyclic rings at C-2 and C-7 amide pendant positions of the tetramate core 1 (Figure 1), which was expected also to correlate with a decrease in lipophilicity and an increase in aqueous solubility. In particular, C-2 t-butyl or phenyl groups $\left(R^{1}\right)$ present in previously synthesised tetramate analogues were replaced with pyridine rings $\left(R^{1}\right)$, and C-7 amide pendants $\left(R^{2}\right)$ were 4-chloro-2-methyl-benzyl, cyclohexyl, adamantyl and polar tetrahydropyranyl groups. 

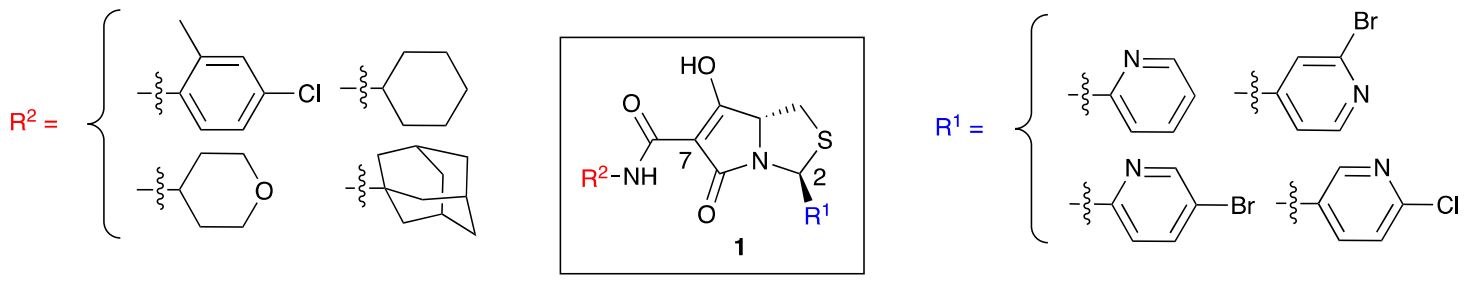

Figure 1

Figure 1. Tetramate analogues

\section{Results and Discussion}

We have earlier reported a synthetic pathway leading to highly functionalised bicyclic tetramic acid derivatives with high enantiopurity, starting from L-serine, L-threonine and Lcysteine, ${ }^{18}$ beginning with a method developed by Seebach and co-workers, ${ }^{22,23}$ in which methyl esters of respective amino acids were condensed with pivaldehyde ( $t$-BuCHO) to yield oxazolidines or thiazolidines as a mixture of cis/trans-2,5 diastereomers. This was followed by $\mathrm{N}$-acylation and Dieckmann cyclisation to give bicyclic tetramates (Scheme $1, \mathrm{R}^{1}=t$-Bu); the chemo-, diastereo- and enantioselectivity of this process is controlled by the bulky C- 2 -butyl group. ${ }^{18}$ Although there was some reported precedent of the synthesis of highly functionalised bicyclic lactam systems with endo-substituents, they were found to be much less stable than the corresponding exosubstituents. ${ }^{24,25}$ This route of cyclisation was favoured even though the reaction proceeded via a relatively unstable enolate formation. It was later shown that this sequence could be run with isobutyraldehyde or substituted benzaldehydes in both L-serine-derived oxazolidine systems and L-cysteine-derived thiazolidine systems, and while the oxazolidine systems were found not to be as stable, thiazolidine systems derived from L-cysteine and substituted benzaldehydes allowed greater variations at $\mathrm{C}-2$ without compromising the heterocyclic stability (Scheme $\left.1, \mathrm{R}^{1}=\mathrm{Ar}\right) .{ }^{20}$ Noteworthy was that this substitution modified the chemoselectivity of the Dieckmann cyclisation to favour the formation of tetramate C-5 esters, allowing for convenient late-stage functionalisation to tetramate carboxamides by transamidation reactions. ${ }^{19,20}$ With this in mind, the immediate question was whether this approach could be extended to heterocyclic aldehydes 
(Scheme 1, R $\mathrm{R}^{1}=\mathrm{Het}$ ), allowing incorporation of heterocycles at both $\mathrm{C}-2$ and $\mathrm{C}-7$, generating the target cysteine-derived tetramate library to increase molecular polarity.

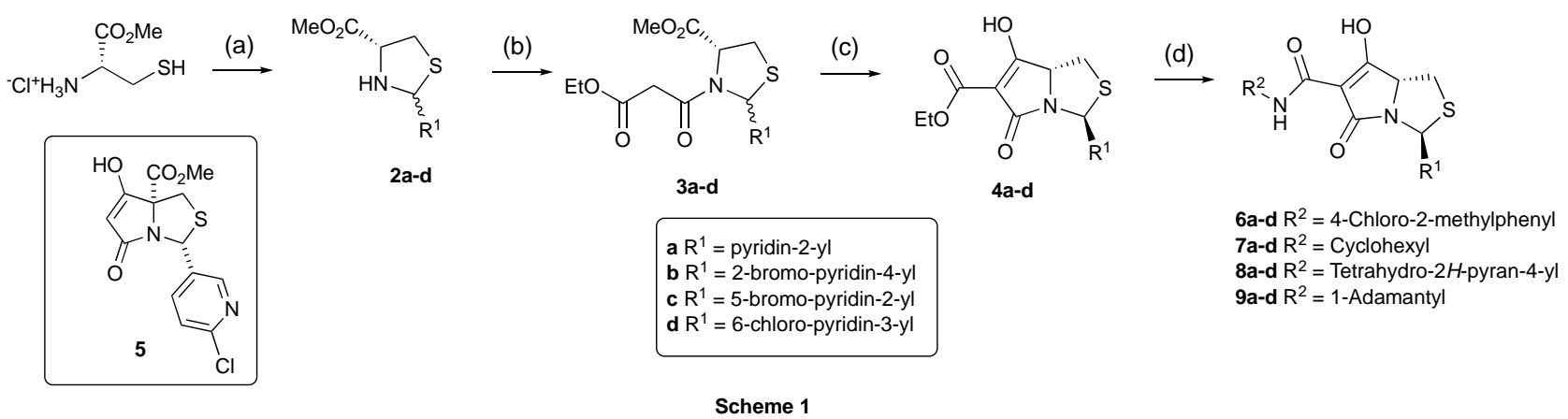

Scheme 1. Synthesis of tetramate analogues from L-cysteine methyl ester $\mathrm{HCl}$. Reagents and conditions: (a) $\mathrm{R}^{1} \mathrm{CHO}, \mathrm{Et}_{3} \mathrm{~N}$, petrol 40/60, reflux under Dean-Stark conditions, $18 \mathrm{~h}$; (b) mono-ethyl malonate, DCC, DMAP, DCM, $0{ }^{\circ} \mathrm{C}$ to r.t., $18 \mathrm{~h}$; (c) $\mathrm{KO}{ }^{t} \mathrm{Bu}$, THF, reflux, $4 \mathrm{~h}$; (d) $\mathrm{R}^{2} \mathrm{NH}_{2}$, THF/toluene (1: 4), reflux, $18 \mathrm{~h}$.

Condensation of L-cysteine methyl ester hydrochloride with four different pyridinecarboxaldehydes gave the corresponding stable thiazolidines $\mathbf{2 a - d}$ in good yield $(75-86 \%$, Scheme 1 and Table $1, \mathrm{SI}$ ) as a mixture of cis- and trans-diastereomers in approximately equal ratio. They were readily distinguished by a difference in the chemical shifts of $\mathrm{H}-2$ and $\mathrm{H}-5$, with that of the trans-isomer being more downfield than the cis-isomer (Table 1, SI), consistent with that previously found in thiazolidines with C-2 substituted aromatic rings. ${ }^{20}$ The assignment of stereochemistry was further confirmed by NOE analysis, where the presence of an enhancement between $\mathrm{H}-5$ proton and an aromatic proton suggested trans-stereochemistry and an enhancement between $\mathrm{H}-5$ and $\mathrm{H}-2$ protons suggested cis-stereochemistry (Figure $1, \mathrm{SI}$ ).

Thiazolidines 2a-d, as a diastereomeric mixture, were converted by DCC coupling with mono-ethyl malonate to the corresponding $N$-acylthiazolidines 3a-d in high yield (77 - 92\%, 
Scheme 1 and Table 2, SI) with a cis/trans ratio favouring the former, as has been found previously. ${ }^{20}$

Similar to thiazolidines $\mathbf{2 a - d}$, characteristic $\mathrm{H}-\mathbf{2}$ chemical shifts of the acylated products $\mathbf{3 a -}$ d were observed, with each diastereomer appearing as a rotameric pair. For $\mathbf{3 a}$, the cis- and transdiastereomers could be separated by flash column chromatography, and the assignment of relative stereochemistry was supported by $1 \mathrm{D}$ NOE analysis (Figure 1, SI). Although 2D NOESY experiments were not sensitive enough to detect weak nOe effects in this case, they nonetheless also confirmed the presence of rotamers around the amide bond in the $N$-acylthiazolidine series (Figure 2); thus, between the pair of rotamers from the same diastereomer, there were reproducible and dynamic proton exchanges, which could be distinguished from NOE signals in the 2D NOESY spectrum (Figure 2, SI). In 2D NOESY spectra of small molecules ( $\mathrm{MW} \leq 500$ ) in low viscosity solvent (e.g. $\mathrm{CDCl}_{3}$ ), peaks arising from chemical exchange processes have the same sign as the diagonal (red) while NOE cross peaks (blue) are of opposite sign. ${ }^{26}$ Cross peaks $(6.48,6.20)$ or $(6.20,6.48)$ of $\mathrm{H}-2$ chemical shifts, which were of the same sign as the diagonal peaks, indicated that they arose from dynamic chemical exchange and hence supported that these chemical shifts belonged to a pair of rotamers arising from the same diastereomer.

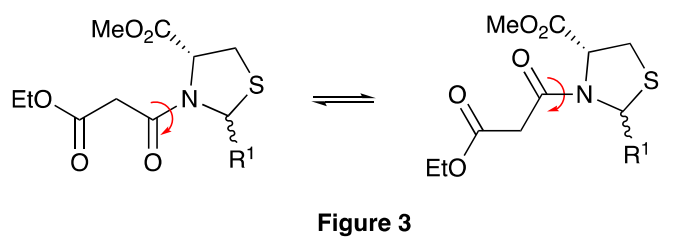

Figure 2. Rotameric behaviour of $\mathrm{N}$-acylthiazolidines from amide bond rotation.

Moreover, it was observed that for the major and minor rotamers of $\mathrm{N}$-acylthiazolidines 3a-d, the H-2 chemical shift of the trans-isomer was invariably more upfield than that of the cisisomer (Table 2, SI), which was opposite to that observed in the thiazolidine series (Table 1, SI). The change in the cis/trans ratio from the starting thiazolidines $\mathbf{2 a - d}$ to $\mathrm{N}$-acylthiazolidines $\mathbf{3 a - d}$ 
suggested an interconversion between the two diastereomers during the course of acylation, with the equilibrium leading to a preferred formation of the cis-malonylthiazolidines, and allowing an all-equatorial arrangement around the heterocyclic ring; this type of behaviour has been observed previously in C-2 t-butyl and isopropyl series. ${ }^{18}$

Dieckmann cyclisation of $N$-acylthiazolidines $3 a-d$ with $\mathrm{KO}^{t} \mathrm{Bu}$ successfully gave stable bicyclic tetramate ester products $4 \mathbf{a}-\mathbf{d}$ in $35-48 \%$ yield, which existed as the enol tautomer as observed by ${ }^{1} \mathrm{H}$ NMR spectroscopy, and with characteristic $\mathrm{H}-2$ and $\mathrm{H}-5$ chemical shift values for the bicyclic ring system consistent to those previously reported in thiazolidine-derived tetramate esters with C-2 substituted aromatic rings (Table 3, SI). ${ }^{20}$ These were formed as single diastereomers with a trans relationship between $\mathrm{H}-2$ and $\mathrm{H}-5$ across the bicyclic ring systems, which was confirmed by NOE analysis for 4 a (Figure 1, SI). On the basis of the consistent and characteristic $\mathrm{H}-2$ chemical shifts, the same stereochemistry was assigned for other tetramate esters $\mathbf{4 b - d}$ in the series.

The predominant pathway of cyclisation starting from the trans-malonylthiazolidines, trans-3a-d to tetramates $4 a-d$ suggested that the reaction proceeded preferentially by closure of the side chain malonamide enolate onto the C-5 ester (Scheme 2, type A), which also placed the C2 heterocycles on the less hindered exo-face of 4 . This preferred route of ring closure was consistent with that previously observed in thiazolidine derived systems with C-2 aromatic rings. ${ }^{20}$ The alternatively cyclised product 5 (Scheme 1) was detected by mass spectrometry from the reaction of $\mathbf{3 d}$ in $3 \%$ yield, the NOE analysis of which suggested a relative cis-stereochemistry between C-2 substituent and C-5 methyl ester (Figure 1, SI); in this case, cyclisation starting from cis-3d proceeded by closure of the less stable C- 5 enolate onto the ethyl ester (type $\mathbf{B}$, Scheme 2), which preferentially placed the C-2 group on the exo-face. This minor route of cyclisation was also reported previously in thiazolidine derived systems with C-2 aromatic rings to occur in $<1 \%$ yield. ${ }^{20}$ Furthermore, a further Dieckmann cyclisation could occur after epimerisation at C-5 of cis- 
3 under the basic conditions of the reaction giving ent-trans-3. Since the cis- and transdiastereomers of malonamides $\mathbf{3 b}$ - $\mathbf{d}$ could not be easily separated and the mixture was used for the subsequent Dieckmann cyclisation, this simultaneous epimerisation and cyclisation gave concerns about erosion of enantiopurity for the products. In the case of $\mathbf{3 a}$, the two diastereomers were able to be separated by flash column chromatography and each was used for separate cyclisation. Reaction of malonamide trans-3a with $\mathrm{KO}^{t} \mathrm{Bu}$ successfully gave the cyclised product 4a as expected. However, attempted cyclisation of cis-3a only gave degraded product, indicating that cyclisation after epimerisation of cis-3a was not observed (cyclisation via type C enolate, Scheme 2).<smiles>CCOC(=O)CC(=O)N1CCC[C@H]1C(C)=O</smiles>

ent-trans-3

$\downarrow$ not observed<smiles>CCOC(=O)C1=C(O)[C@@H]2CS[C@@H]([Tl])N2C1=O</smiles>

ent-4<smiles>CCCC1CSC(CC(=O)OC)N1C(=O)OCC</smiles>

C<smiles>CCOC(=O)CC(=O)N1[C@H](C(=O)OCC)CC[C@H]1C</smiles>

cis-3<smiles>[3H][13CH2][13CH2][13CH3]</smiles>
O $\mathrm{CO}_{2} \mathrm{Me}$<smiles>CCCN1C(=O)CC(=O)C1(C)C</smiles>

5, $3 \%$<smiles>CCCC1(C)CSC(CCC(=O)OCC)N1C(=O)CO</smiles>

cheme 2

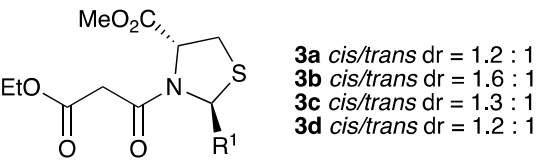

trans-3<smiles>CCCC1SC[C@H]2C(OC)=C(C(=O)OCC)C(=O)N12</smiles>

4, $35-48 \%$<smiles>[1H]C1SC[C@@H](C(=O)OC)N1C(=O)OC(=O)CC</smiles>

A a $\mathrm{R}^{1}=$ pyridin-2-yl

b $\mathrm{R}^{1}=2$-bromo-pyridin-4-yl c $\mathrm{R}^{1}=5$-bromo-pyridin-2-yl d R $^{1}=6$-chloro-pyridin-3-yl

Scheme 2. Synthesis of thiazolidine-derived tetramates with C-2 pyridine rings.

In order to understand the switch of chemoselectivity of Dieckmann cyclisation after substituent change at C-2 from a bulky t-butyl or isopropyl group to a planar aromatic system (substituted phenyl rings or heterocycles), density-functional theory (DFT) calculations were carried out to model the energy profile of the cyclisation process in thiazolidine systems with C-2 t-butyl group and phenyl ring. To simplify the model, the calculations assumed that the various 
enolates were in free equilibrium (Scheme 3 and Figure 3). In the cyclisation of $N$-acylthiazolidines 9 with a C-2 $t$-butyl group, the major C-5 methyl ester tetramate product 10 (AProduct2, 57\% yield) formed from cis-9 (A) following the energy pathway with the lowest activation energy $($ Ea $=5.3$ $\mathrm{kcal} / \mathrm{mol}$ ). The alternative pathway from the same starting material $\mathbf{9}$ to $\mathbf{1 1}$ (AProduct1), which placed the C-2 t-butyl group onto the endo-face of the bicyclic ring, required a much higher activation energy $(\mathrm{Ea}=17.8 \mathrm{kcal} / \mathrm{mol})$. The significant difference in these activation energies $(\Delta \mathrm{Ea}$ $=12.5 \mathrm{kcal} / \mathrm{mol}$ ) strongly kinetically favoured the pathway leading to $\mathbf{1 0}$ (AProduct2), which was also the more stable product (minimum energy $=-75.4 \mathrm{kcal} / \mathrm{mol}$ ) as compared to 11 (AProduct1) (minimum energy $=-70.8 \mathrm{kcal} / \mathrm{mol})$. The other tetramate product 12 (BProduct1) from trans $-\mathbf{9}$ was not observed because the previous step of $\mathbf{N}$-acylation resulted in an exclusive formation of cis-9. Given that 12 (BProduct1) possessed the lowest energy (minimum energy $=-78.8 \mathrm{kcal} / \mathrm{mol}$ ) and that the activation energy $(\mathrm{Ea}=7.7 \mathrm{kcal} / \mathrm{mol})$ was not significantly higher $(\mathrm{Ea}=7.7 \mathrm{kcal} / \mathrm{mol}), 12$ (BProduct1) could potentially form if the trans-9 had been present; the formation of an analogous product was indeed observed in related work, but only with $4 \%$ yield. ${ }^{27}$ This model suggested that for malonamides with C-2 $t$-butyl group, the Dieckmann cyclisation operated under strong kinetic control. 


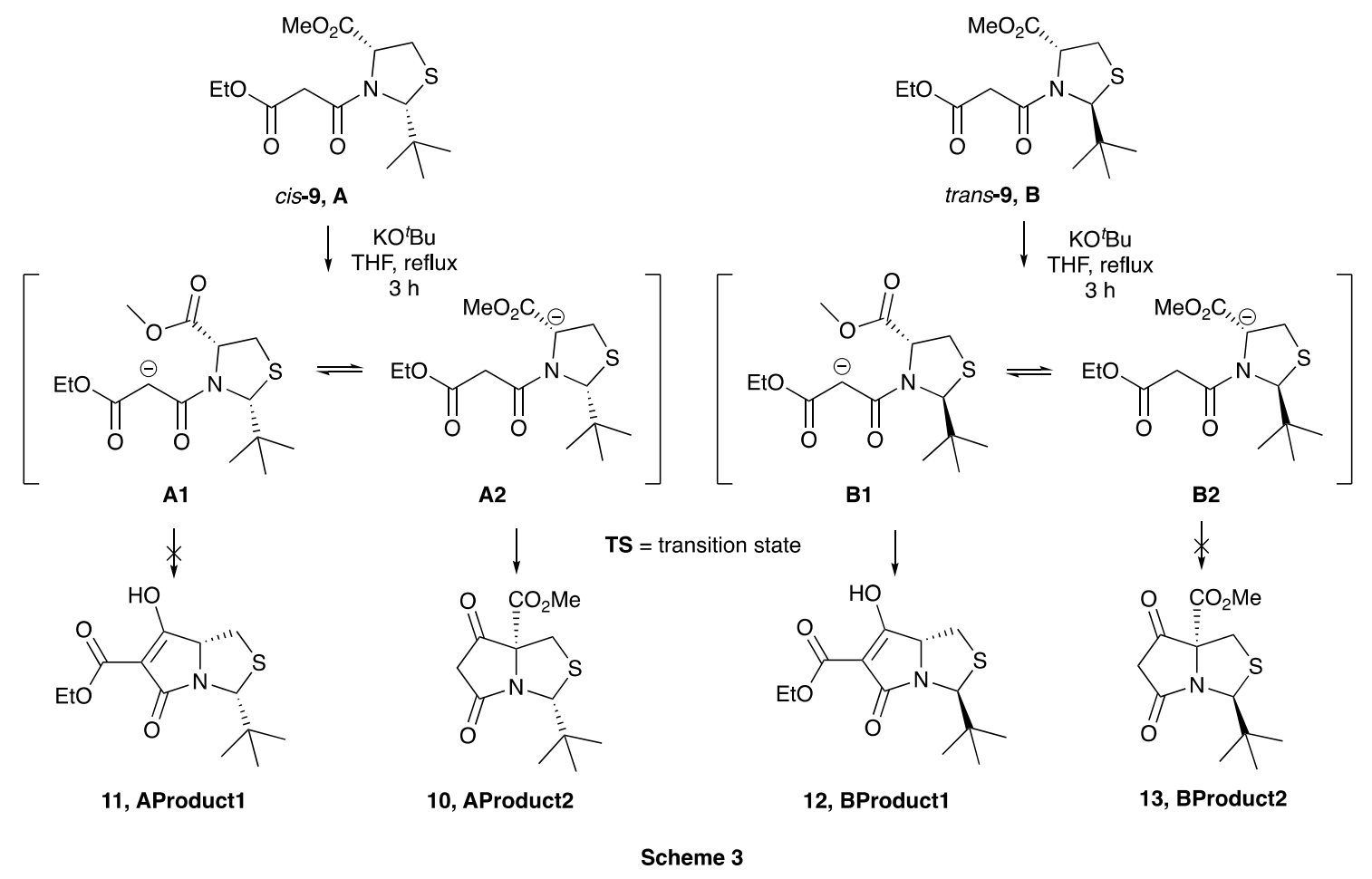

Scheme 3. Cyclisation pathway of malonamides $\mathbf{9}$. 


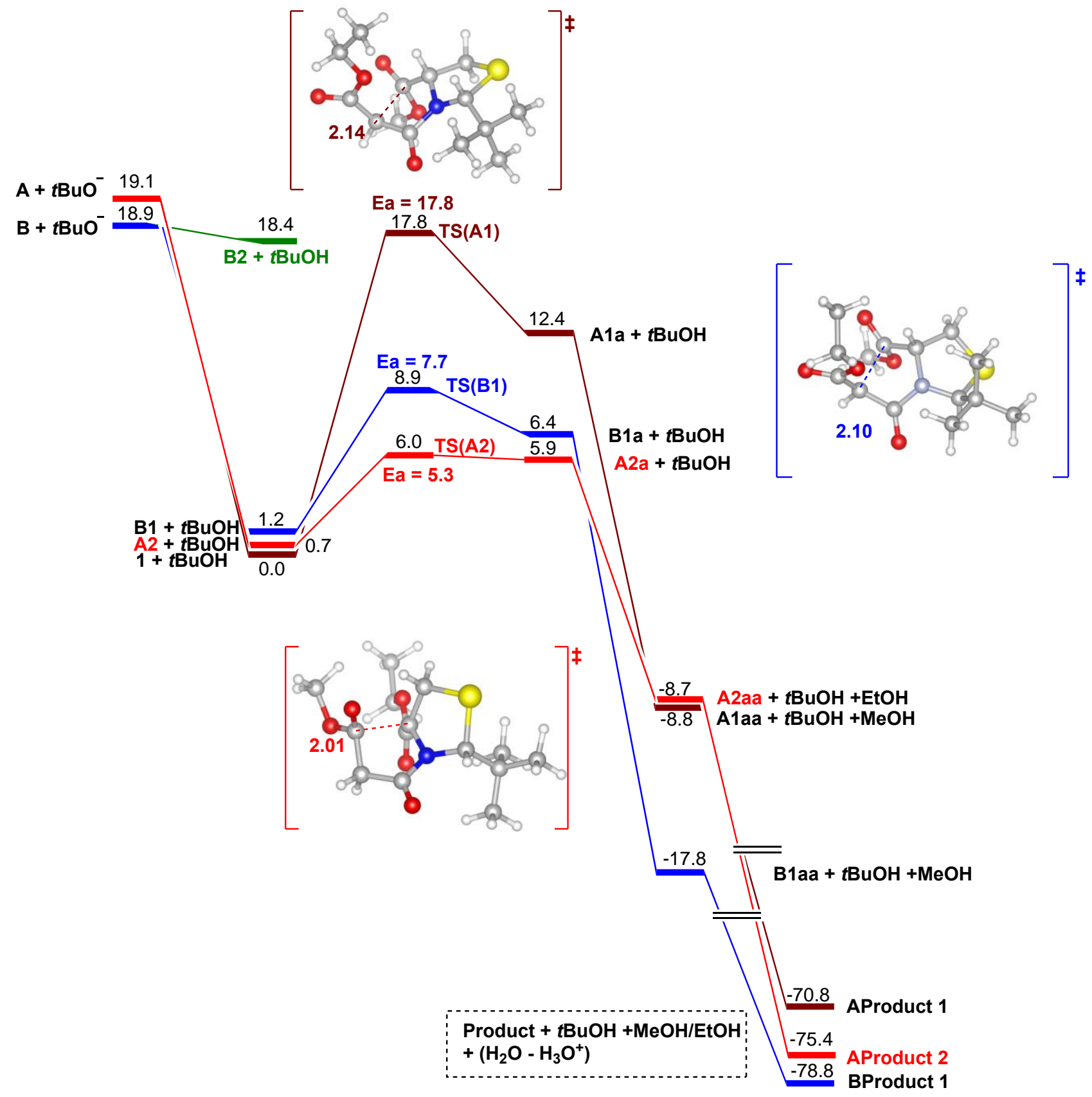

Figure 3. Reaction energy profile of Dieckmann cyclisation for malonamides of C-2 $t$-butyl group.

Calculated potential energy surfaces at the B3LYP/6-311++G $(d, p)$ level of theory with SMD solvation (THF). All energies are reported in $\mathrm{kcal} / \mathrm{mol}$ and referenced to the lowest energy carbanion generated after initial deprotonation. Labels: A=cis-9, B=trans-9, AProduct1=11, AProduct2=10, BProduct1=12, BProduct2=13; TS = Transition State (see Scheme 3). Energy values in $\mathrm{kcal} / \mathrm{mol}$. 
By comparison, tetramate ester 15 (DProduct1) was formed as the major product (43\% yield) in the cyclisation of cis- and trans-malonylthiazolidines 14 with C-2 phenyl group (Scheme 4 and Figure 4), the pathway starting from trans-14 (D), with the more stable side chain enolate intermediate (D1) closing onto the C-5 ester. Product 15 (DProduct1) appeared to be the thermodynamic product of this process with minimum energy at $-75.2 \mathrm{kcal} / \mathrm{mol}$, although the difference in energy between the alternatives 18 (CProduct1) and 17 (CProduct2) was small. The pathway from cis-14 (C) favoured the formation of $\mathbf{1 7}$ (CProduct2) with the least activation energy $(\mathrm{Ea}=7.4 \mathrm{kcal} / \mathrm{mol})$ of all represented pathways and a smaller minimum energy as compared to 18 (CProduct1). The reason why $\mathbf{1 7}$ (CProduct1) was only observed in < 1\% yield from a starting mixture enriched in cis-14 $(\mathrm{J})(\text { cis/trans }=1.7: 1)^{20}$ could not be explained by this model. In contrast to the C-2 $t$-butyl series, Dieckmann cyclisation for malonamides with $\mathrm{C}-2$ aromatic rings appeared to be no longer under a strong kinetic control; thermodynamic control appeared to account for the observed chemoselectivity in the reaction in this case.
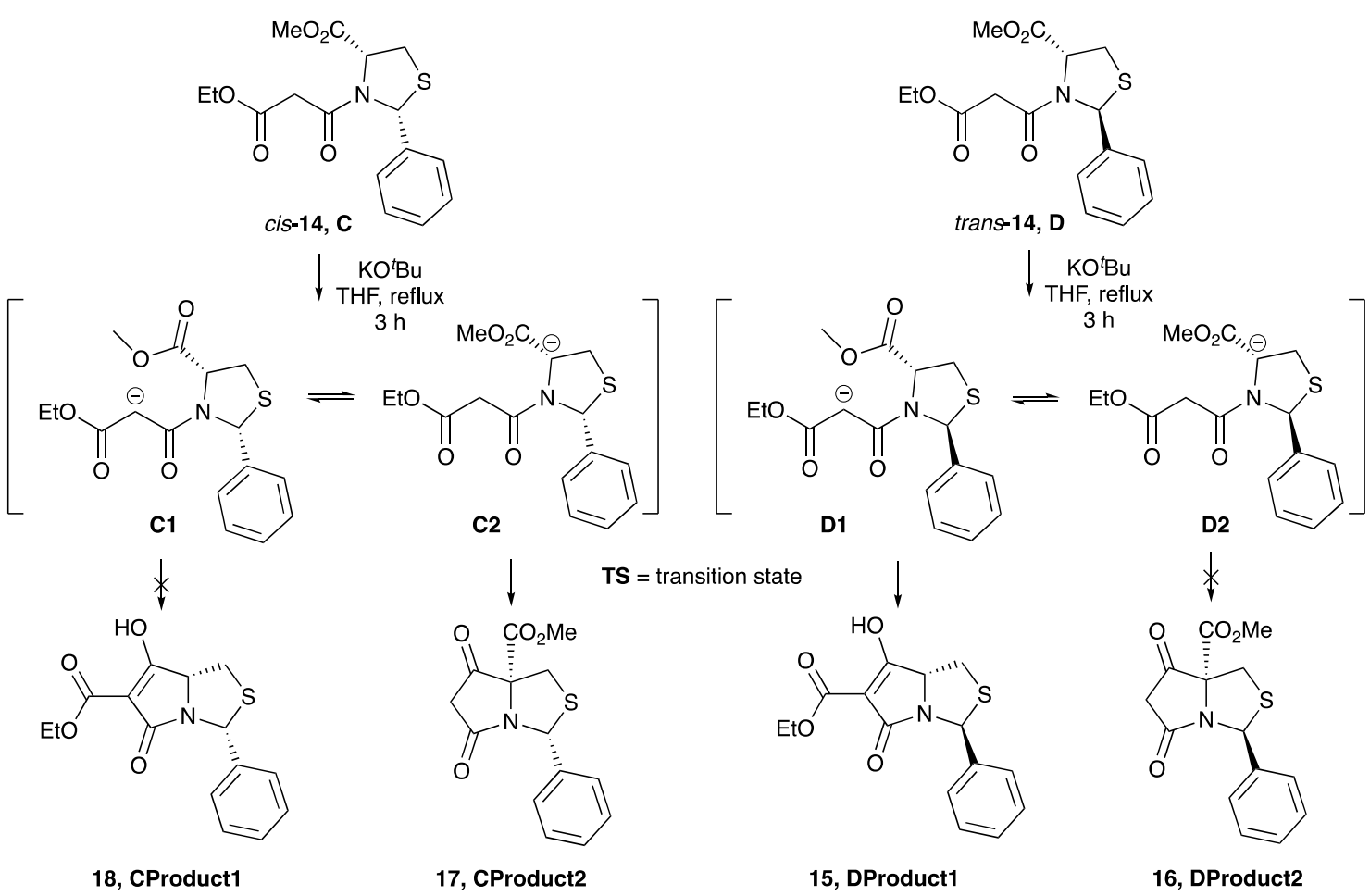

Scheme 4

Scheme 4. Cyclisation pathway of malonamides 14 . 


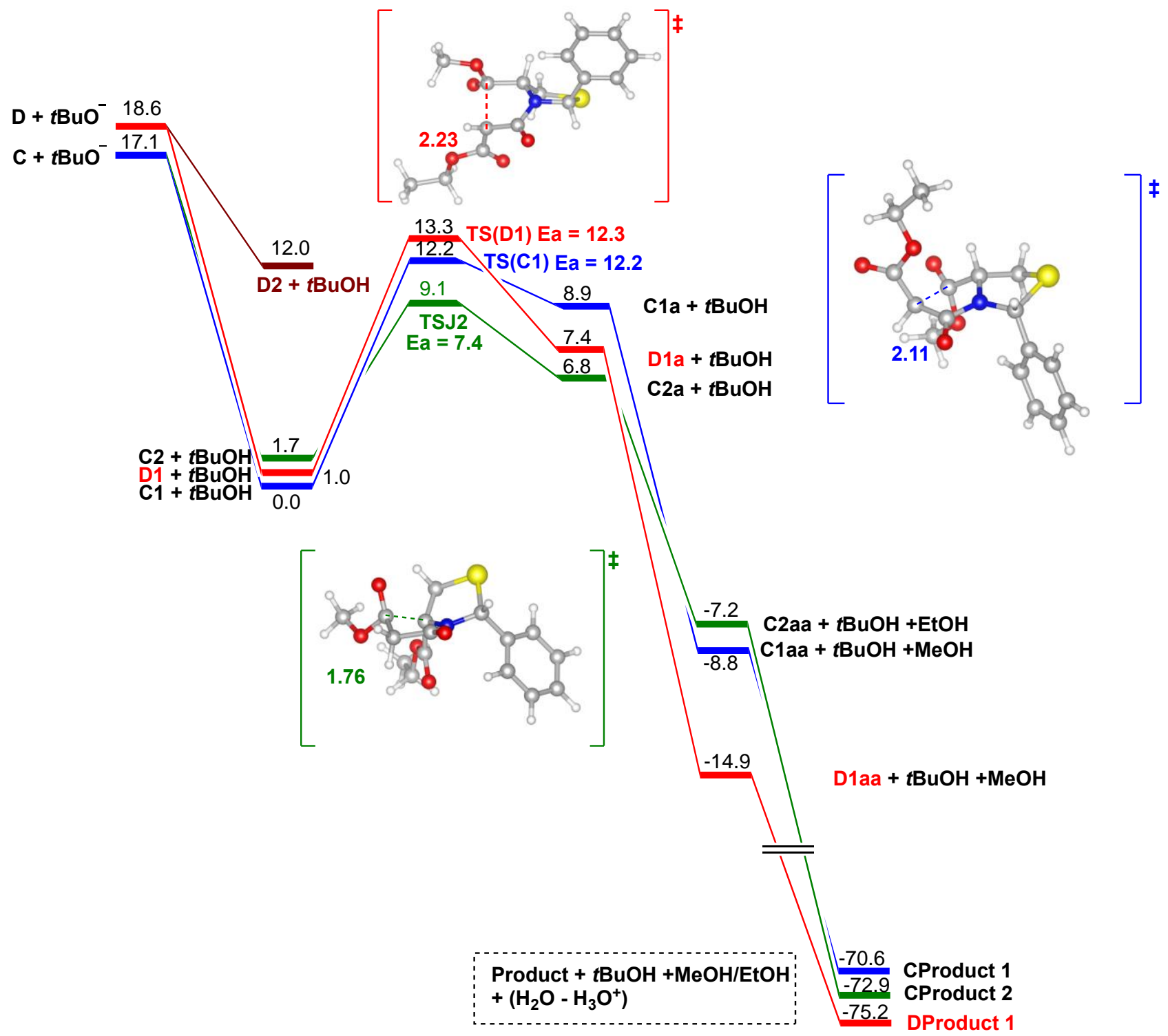

Figure 4. Reaction energy profile of Dieckmann cyclisation for malonamides with C-2 phenyl group.

Calculated potential energy surfaces at the B3LYP/6-311++G $(d, p)$ level of theory with SMD solvation (THF). All energies are reported in $\mathrm{kcal} / \mathrm{mol}$ and referenced to the lowest energy carbanion generated after initial deprotonation. Labels: C=cis-14, D=trans-14, DProduct1=15, DProduct2=16, CProduct1=18, CProduct2=17 (see Scheme 4). Energy values in $\mathrm{kcal} / \mathrm{mol}$.

The tetramate esters $\mathbf{4 a - d}$ were further functionalised by direct ester to amide conversion

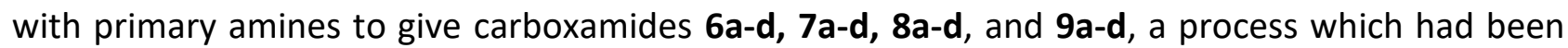
found to be effective in other systems. ${ }^{19}$ Some reactions did not go to completion when run in 
THF/toluene at reflux for $18 \mathrm{~h}$ and yields varied (10-70\%, Table 3). The trans-ring stereochemistry was expected to be conserved during the course of reaction and products all showed characteristic $\mathrm{H}-2$ and $\mathrm{H}-5$ chemical shift data (Table 3). The trans- stereochemistry was further supported by NOE analysis of $9 \mathbf{d}$, indicating an enhancement between $\mathrm{H}-5$ and aromatic $\mathrm{H}-2^{\prime}$ protons (Figure 1, SI). 
Table 1. Yield, $\mathrm{H} 2$ and $\mathrm{H} 5$ chemical shifts $\left(\mathrm{CDCl}_{3}, 400 \mathrm{MHz}\right)$ for tetramate carboxamides.

\begin{tabular}{|c|c|c|c|c|c|}
\hline & \multirow{2}{*}{$\mathbf{R}^{2}=$} & \multirow{2}{*}{$\mathbf{R}^{1}=$} & \multicolumn{2}{|c|}{$\delta_{H}(p p m)$} & \multirow{2}{*}{$\%$ Yield } \\
\hline & & & $\mathrm{H}-2$ & $\mathrm{H}-5$ & \\
\hline $6 a$ & & & 6.35 & 5.11 (br.s) & 70 \\
\hline $6 b$ & & & 6.18 & $4.81(a p p t)$ & 52 \\
\hline $6 c$ & & & 6.28 & $5.08(a p p t)$ & 62 \\
\hline $6 d$ & & & 6.24 & $4.82(\mathrm{app} t)$ & 67 \\
\hline $7 a$ & & & 6.33 & 4.84 (br. s) & 41 \\
\hline \multirow{2}{*}{ 7b } & & & 6.16 (major) & 4.61 (major, br. s) & \multirow{2}{*}{15} \\
\hline & & & 6.24 (minor) & 4.73 (minor, br. s) & \\
\hline $7 c$ & & & 6.25 & 4.81 (br.s) & 31 \\
\hline $7 d$ & & & 6.24 & 4.59 (br. s) & 24 \\
\hline \multirow{2}{*}{$8 b$} & & & 6.14 (major) & 4.67 (major, br. s) & \multirow{2}{*}{12} \\
\hline & & & 6.20 (minor) & 4.39 (minor, dd) & \\
\hline \multirow{2}{*}{$8 c$} & & & 6.30 (major) & 4.90 (major, app t) & \multirow{2}{*}{10} \\
\hline & & & 6.25 (minor) & - & \\
\hline $9 a$ & & & 6.31 & 4.84 (br. s) & 44 \\
\hline $9 b$ & & & 6.17 & 4.48 (br. s) & 33 \\
\hline \multirow{2}{*}{$9 c$} & & & 6.25 (major) & $4.81(\operatorname{app} t)$ & \multirow{2}{*}{38} \\
\hline & & & 6.33 (minor) & 4.57 (app t) & \\
\hline \multirow{2}{*}{ 9d } & & & 6.23 (major) & 4.59 (app t) & \multirow{2}{*}{35} \\
\hline & & & 6.31 (minor) & - & \\
\hline
\end{tabular}

Tautomeric behaviour was known to exist for 3 -acyltetramic acids in solution. ${ }^{13,28}{ }^{1} \mathrm{H}$ NMR spectra for these tetramate carboxamides indicated complete enolisation, with no chemical shift 
for $\mathrm{H}-7$ being detected. Thus, tautomeric pairs $\mathbf{A B}$ and $\mathbf{C D}$ are internal tautomers which rapidly exchange with each other through proton transfer, and averaged signals were observed for $\mathbf{A B}$ and CD on the NMR time scale (Figure 5). Only the external tautomers, between the endo-enolic pair $\mathbf{A} / \mathbf{C}$ and between the exo-enolic pair $\mathbf{B} / \mathbf{D}$, could be detected by NMR spectroscopy, with distinct ${ }^{1} \mathrm{H}$ and ${ }^{13} \mathrm{C}$ chemical shifts. The assignment of the chemical shifts for carbonyl functional groups C-6, C-8 and C-9 was supported by HMBC analysis, which also confirmed the assignment of the tautomeric forms. The chemical shifts of $\mathrm{H}-2$ and carbonyl carbons ( $\mathrm{C}-6, \mathrm{C}-8, \mathrm{C}-9)$ showed a similar pattern for the major/minor tautomers across the series (Table 2), which was also consistent with that observed in previously reported tetramate carboxamides with C-2 aromatic rings. ${ }^{19}$

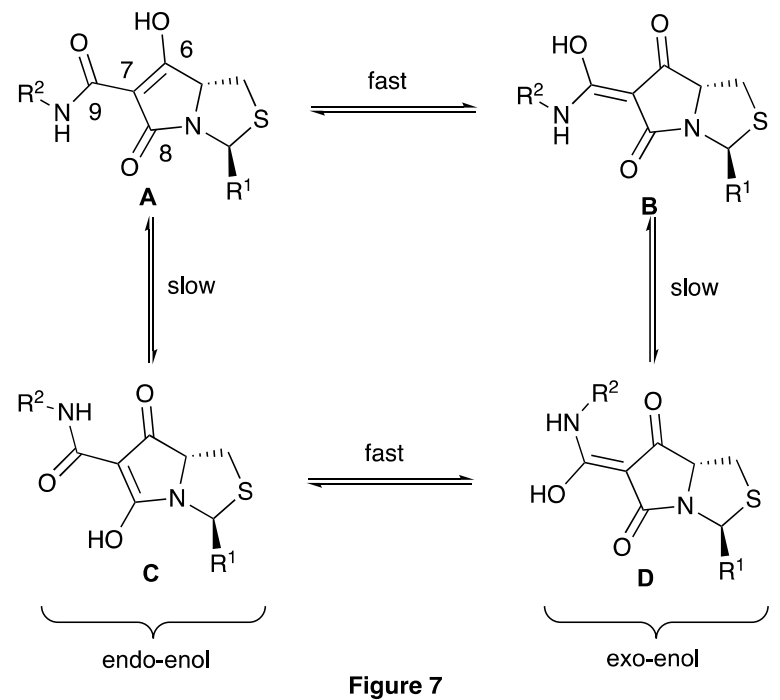

Figure 5. Tautomeric behaviour of tetramate carboxamides.

Table 2. H-2 and C-6, C-8, C-9 chemical shifts $\left(\mathrm{CDCl}_{3}\right)$ of tetramate carboxamides.

\begin{tabular}{|c|c|c|c|c|c|c|c|}
\hline & \multirow{2}{*}{$R^{2}=$} & \multirow{2}{*}{$R^{1}=$} & \multicolumn{4}{|c|}{$\delta_{H}(p p m)$} & \multirow{2}{*}{$\mathrm{AB} / \mathrm{CD} \mathrm{D}^{[\mathrm{a}]}$} \\
\hline & & & $\mathrm{H}-2$ & $C-6$ & $C-8$ & C-9 & \\
\hline $6 a$ & & & 6.35 & 188.0 & - & 163.8 & AB only \\
\hline $6 b$ & & & 6.18 & 184.9 & 172.3 & 163.6 & AB only \\
\hline
\end{tabular}




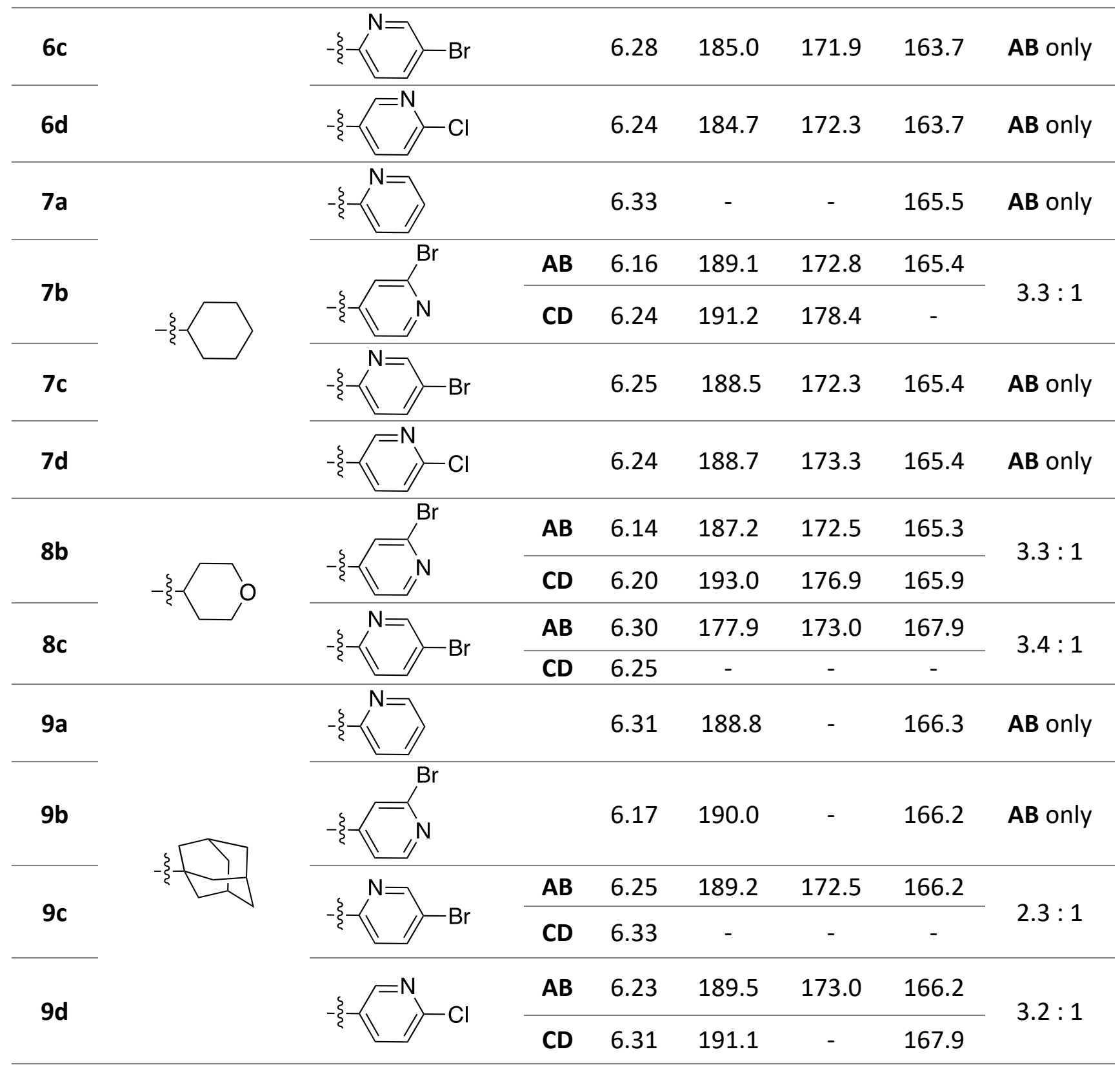

[a] The tautomeric ratio $A B / C D$ was calculated as the ratio of integration of $\mathrm{H}-2$. - in most cases where sample mass was low, routine ${ }^{13} \mathrm{C}$ NMR was not sensitive enough to detect all ${ }^{13} \mathrm{C}$ signals for minor tautomers.

The purification of tetramate esters and carboxamides by flash silica column chromatography has been reported to result in broadening of signals in ${ }^{1} \mathrm{H}$ NMR spectra; this has been attributed to the formation of metal chelates during the chromatographic process from trace amounts of metal impurities. ${ }^{19,} 20,28$ This problem could be solved by running chromatography with $1 \% \mathrm{Et}_{3} \mathrm{~N}$ in the eluant, and subsequently washing with $5 \%$ citric acid to give metal freetetramates with improved signal sharpness and resolution. ${ }^{19}, 20$ However, the presence of a basic 
pyridine ring $(\mathrm{pKa}=5.23)$ in the tetramate systems 4-9 limited the acid strength for post-column washing and also inevitably resulted in loss of yield to high solubility in the acidic aqueous layer. In order to probe metal chelating properties further, after characterisation of the post-column and acid-washed compound by ${ }^{1} \mathrm{H}$ NMR spectrometry, a metal-free sample of tetramate ester $4 \mathrm{c}$ was re-dissolved in DCM and washed with $1 \mathrm{M}$ aqueous solutions of metal ions. Comparison of the ${ }^{1} \mathrm{H}$ NMR spectra clearly showed line broadening of metal chelated forms, relative to the clean material 4c (Figure 6); thus, tetramate carboxamides appeared to bind more strongly with metals than tetramate esters (Figure 6, A versus E), and stronger binding to $\mathrm{Fe}^{2+}$ as compared to $\mathrm{Ca}^{2+}$ (Figure 6, C versus D).
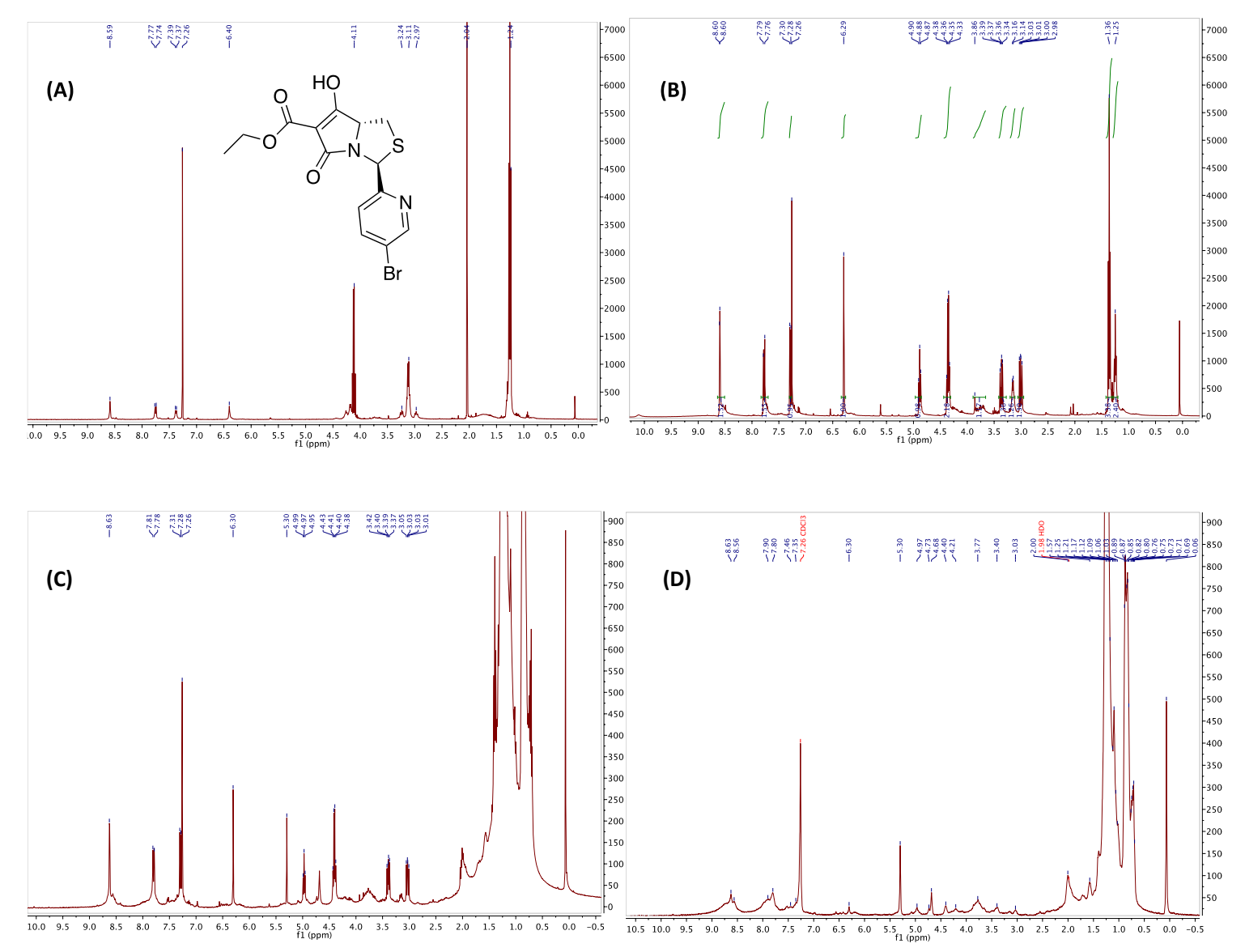

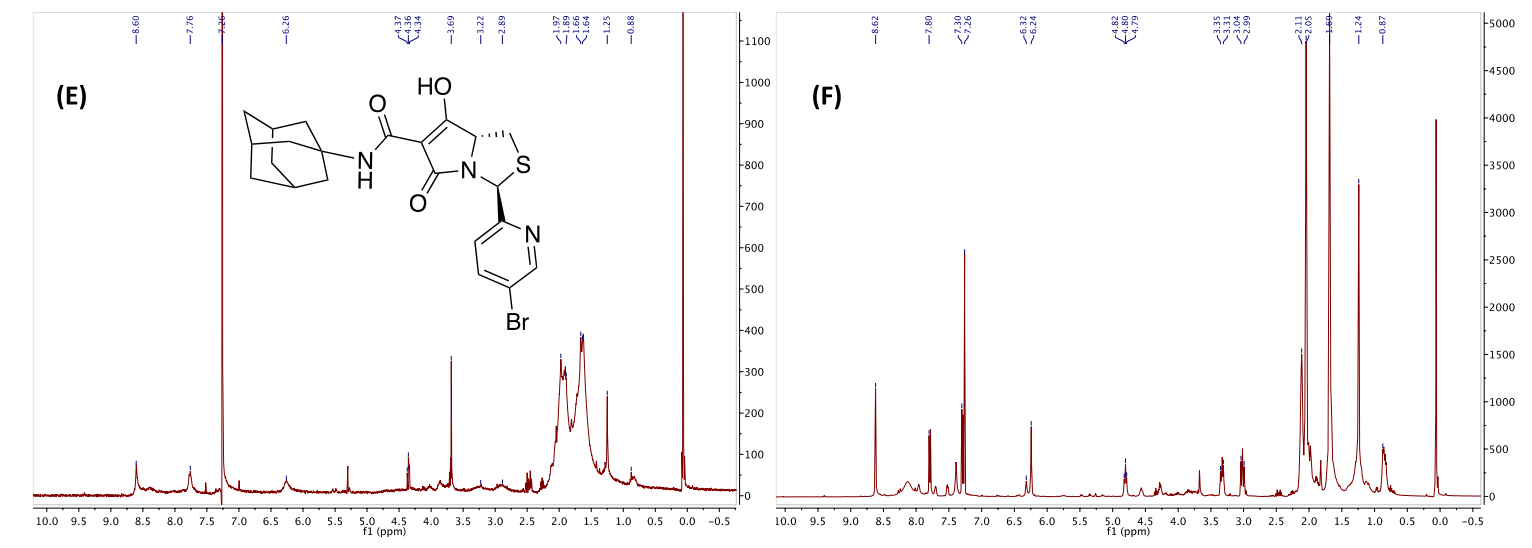

Figure 6. ${ }^{1} \mathrm{H} \mathrm{NMR}\left(\mathrm{CDCl}_{3}, 400 \mathrm{MHz}\right)$ spectra indicating metal-chelation abilities of tetramate ester 4c and tetramate carboxamide 9c. (A) Tetramic ester 4c post-column, before acidic wash; (B) tetramic ester 4c post-column, after 5\% citric acidic wash; (C) metal-free 4c washed with aq. $1 \mathrm{M}$ $\mathrm{Ca}\left(\mathrm{NO}_{3}\right)_{2}$ solution; (D) metal-free $4 \mathrm{c}$ washed with aq. $1 \mathrm{M} \mathrm{FeSO}$ solution; (E) Tetramic carboxamide 9c post-column, before acidic wash; (F) tetramic carboxamide 9c post-column, after 5\% citric acidic wash.

\section{Biological evaluation}

The tetramate esters $\mathbf{4 a - d}$ and carboxamides $6 a-d, 7 a-d, 8 a-d$ and $9 a-d$ were tested for their biological activities against Gram-positive methicillin-resistant Staphylococcus aureus (MRSA) and Gram-negative Escherichia coli (E. coli) by minimum inhibitory concentration (MIC) assay; data for the only active compounds is given (Table 3). While good activity was seen against the former, no activity was seen against Gram-negative $E$. coli. In keeping with earlier observations, ${ }^{29}$ none of the tetramate esters $\mathbf{4 a - d}$ showed any activity. Primary evaluation indicated that a hydrophobic pendant at C-7 was essential for bioactivity while substitutions with heterocycles at C-2 successfully increased compound polarity as measured by PSA without compromising bioactivity. Unfortunately, these tetramate analogues were rendered inactive when tested in the presence of blood. We had earlier found that antibacterially active 3-carboxamides exhibited characteristic physicochemical properties $(530<\mathrm{MSA}<600,65<\mathrm{PSA}<80,11<$ rel-PSA $<14,1.2<$ ClogP $<2.5,-1.1<$ 
$\left.C \log D_{7.4}<0\right)^{29}$ and the corresponding data for compounds 9a-d fit comfortably within these bounds; the limited structural scope of this library, however, does not permit a meaningful SAR analysis to be made, although the inactivity of the tetrahydropyranyl and chloromethylphenyl series is consistent with our earlier observation that polar groups at this position generally compromise phenotypic antibacterial activity. ${ }^{29}$ That distinct antibacterial classes exhibit characteristic mean values for their physicochemical properties has been reported by O'Shea and Moser. ${ }^{30}$

Table 3. Biologically active cysteine-derived tetramate analogues.

9d

[a] Relevant chemical properties of the active compounds were calculated using MarvinSketch 16.10 .

\section{Conclusion}

The synthesis of cysteine-derived bicyclic tetramate analogues with C-2 and C-7 substitutions, which is highly chemoselective and stereoselective, leading to bicyclic tetramate esters and tetramate carboxamides with a trans relationship between $\mathrm{H}-2$ and $\mathrm{H}-5$, has been achieved. The Dieckmann cyclisation proceeded in the same direction to that previously observed 
in C-2 aromatic series, ${ }^{20}$ but in a different manner to that in the C-2 $t$-butyl and isopropyl series, ${ }^{18}$ highlighting the steric control exerted by C-2 substituents on the chemoselectivity of the cyclisation process. Although this allowed increasing polarity of tetramate carboxamides to be achieved by introducing heterocycles at C-2 and C-7 without diminishing in vitro bioactivity, tetramate analogues with polar C-7 pendants were inactive, suggesting that the C-7 amide pendant was not a suitable position for polarity modulation. The tetramate analogues exhibited structure dependent metal chelation properties, influencing compound purification and biological activities. Despite their increase in polarity, these cysteine-derived tetramate analogues lost their potent in vitro bioactivity when tested in the presence of blood.

\section{Experimental}

All reagents were obtained either from Sigma Aldrich, Alfa Aesar or Fluorochem and used without further purification. All reactions were carried out in oven-dried reaction flasks under inert $\left(\mathrm{N}_{2}\right)$ atmosphere unless not using dry solvents. Reaction times were recorded in minutes (min), hours (h) or days (d). Reactions left overnight (o.n.) lasted for 16 - 20 h. 'Petroleum ether' refers to that fraction of light petroleum ether boiling at $40-60{ }^{\circ} \mathrm{C}$ and was used as received. Temperatures below room temperature were obtained using cold baths: $0{ }^{\circ} \mathrm{C}$ (ice/water), $-15{ }^{\circ} \mathrm{C}$ (ice/ $/ \mathrm{NaCl}$ salt) and $-78^{\circ} \mathrm{C}$ (dry ice/acetone). Temperatures above room temperature were obtained with heating with oil bath. Solvents were evaporated at $40{ }^{\circ} \mathrm{C}$ unless otherwise stated under reduced pressure on a Buchi RE 111 Rotavapour attached to a Vacuubrand CVC2 pump and pressure control system. Concentrations $(c)$ in the general procedures referred to the limiting reagent and were given in $\mathrm{mmol} / \mathrm{mL}$. Thin layer chromatography (TLC) was performed using Merck aluminium foil backed sheets precoated with $0.2 \mathrm{~mm}$ Kieselgel $60 \mathrm{~F}_{254}$. Product spots were visualized by UV fluorescence ( $\max 254 \mathrm{~nm}$, for conjugated systems), staining with a $\mathrm{KMnO}_{4}$ solution and heating (for unsaturated systems) or staining with ninhydrin solution and heating (for primary and secondary 
amines). Retention factors $\left(R_{\mathrm{f}}\right)$ were quoted to the nearest 0.01 . Column chromatography was carried out using Sigma Aldrich silica gel 60, 0.040-0.063 (230-400 mesh particle size). The eluents used were determined based on the $R_{f}$ values. Melting points were recorded using a Stuart Scientific SMP1 melting point instrument in open capillaries and were uncorrected. Optical rotations were recorded on a Perkin-Elmer 241 polarimeter at the stated temperature $\left(25^{\circ} \mathrm{C}\right)$ using the $D$ line of sodium (wavelength at $589 \mathrm{~nm}$ ) and a path length of $1 \mathrm{dm}$. Specific rotations $[\alpha]_{\mathrm{D}}^{25}$ were calculated and reported in $10^{-1}{ }^{\circ} \mathrm{C} \mathrm{cm}^{2} \mathrm{~g}^{-1}$ with concentration $c$ given in $\mathrm{g} / 100 \mathrm{ml}$ Infrared (IR) spectra were recorded on a Bruker Tensor 27 FT-IR spectrometer with thin film (oil) or powder (solid). Absorption maxima $\left(v_{\max }\right)$ were reported in wavenumbers $\left(\mathrm{cm}^{-1}\right)$ and only selected peaks were reported. ${ }^{1} \mathrm{H}$ NMR spectra were recorded on AVF $(400 \mathrm{MHz})$ or AVC $(500 \mathrm{MHz})$ spectrometers. ${ }^{13} \mathrm{C}$ NMR spectra were recorded on Bruker AVF spectrometer at $101 \mathrm{MHz}$ or on AVC spectrometer at $126 \mathrm{MHz}$ with proton decoupling and cryogenic detection probe. Chemical shifts $(\delta)$ were reported in parts per million (ppm) and were referenced to the residual solvent peak. The abbreviations used to describe multiplicity were as follows: s (singlet), br. s (broad singlet), d (doublet), dd (double doublet), t (triplet), td (triple doublet), dt (doublet triplet), q (quartet), sept (septet), m (multiplet). Coupling constants (J) were given in Hertz (Hz). 2D-NOESY and 1D-NOE experiments were performed using Bruker AVB400 or AVC (500 MHz) spectrometer. HMBC experiments were recorded on Bruker AVC spectrometer. Low resolution mass spectra $(\mathrm{m} / \mathrm{z})$ were recorded on a Fisons Platform spectrometer using electrospray ionisation (ESI). High resolution mass spectra (HRMS) were recorded on a Bruker $\mu$ TOF (ESI or APCI) spectrometer by the internal service at the Department of Chemistry, University of Oxford. The $\mathrm{m} / \mathrm{z}$ values of major peaks were reported in Daltons and their intensities given as percentages of the base peaks.

\section{General procedure for synthesis of thiazolidines $2 a-d$}


$\mathrm{Et}_{3} \mathrm{~N}$ (1.2 eq.) and respective aldehyde (1.0 eq.) were added to L-cysteine methyl ester hydrochloride (1.2 eq.) in petroleum ether $(c=0.3)$. The mixture was heated under reflux at $110^{\circ} \mathrm{C}$ with continuous removal of water using a Dean-Stark apparatus for $18 \mathrm{~h}$. The reaction mixture was then filtered and washed with diethyl ether and the combined filtrates were concentrated in vacuo and residue was purified by flash column chromatography to give thiazolidines $\mathbf{2 a - d .}$

\section{General procedure for synthesis of $\boldsymbol{N}$-acylthiazolidines $3 a-d$}

A solution of mono-ethyl malonate (1.2 eq.) in dichloromethane (DCM) was added dropwise to a stirred solution of thiazolidine (1.0 eq.), $N, N^{\prime}$-dicyclohexylcarbodiimide (DCC, 1.2 eq.) and 4dimethylaminopyridine (DMAP, 0.1 eq.) in $\mathrm{DCM}(c=0.2)$ at $0{ }^{\circ} \mathrm{C}$. The mixture was stirred at $0{ }^{\circ} \mathrm{C}$ for $15 \mathrm{~min}$ and then at room temperature for $18 \mathrm{~h}$. The reaction mixture was then filtered and the solid washed with DCM and the combined filtrates were concentrated in vacuo and residue was purified by flash column chromatography to give $N$-acylated thiazolidines $3 a-d$.

\section{General procedure for synthesis of tetramate esters $4 a-d$}

Potassium tert-butoxide ( $\mathrm{KO}^{t} \mathrm{Bu}, 1.2$ eq.) was added to a stirred solution of $N$-acylated thiazolidine (1.0 eq.) in dry THF ( $c=0.1$ ) and the mixture was heated under reflux for $4 \mathrm{~h}$. It was then cooled to room temperature, concentrated in vacuo and partitioned between diethyl ether and water. The aqueous layer was carefully acidified with $2 \mathrm{M}$ hydrochloric acid to $\mathrm{pH}=3$ and extracted with ethyl acetate. The combined organic layers were washed with brine, dried with $\mathrm{MgSO}_{4}$, filtered and concentrated in vacuo. The residue was purified by flash column chromatography with $1 \% \mathrm{Et}_{3} \mathrm{~N}$ in the eluent to give the desired product. The product was dissolved in DCM and washed with $5 \%$ citric acid. The combined organic fractions were dried with $\mathrm{MgSO}_{4}$, filtered and concentrated in vacuo to yield the desired tetramate esters $\mathbf{4 a - d .}$ 


\section{General procedure for synthesis of tetramate carboxamides 5a-d, 6a-d, 7a-d and 8a-d}

Amine (1.2 eq.) was added to a stirred solution of tetramate ester (1.0 eq.) in THF/toluene (1:4, $c$ $=0.05)$ and the mixture was heated at reflux for $18 \mathrm{~h}$. It was then cooled to room temperature, concentrated in vacuo and residue was purified by flash column chromatography with $1 \% \mathrm{Et}_{3} \mathrm{~N}$ in the eluent to give the desired product. The product was dissolved in DCM and washed with $5 \%$ citric acid. The combined organic fractions were dried with $\mathrm{MgSO}_{4}$, filtered and concentrated in vacuo to yield the desired tetramate carboxamides 5a-d, 6a-d, 7a-d and 8a-d.

\section{General Procedure for the Evaluation of Antibacterial Activity}

The samples were prepared as $4 \mathrm{mg} / \mathrm{mL}$ solutions of $70 \% \mathrm{DMSO}$ in $\mathrm{MeOH}$, with serial dilution to the desired concentrations where necessary. A $100 \mu \mathrm{L}$ aliquot of each sample solution to be tested was loaded into $10 \mathrm{~mm}$ wells in agar plates and incubated for $24 \mathrm{~h}$ at $35{ }^{\circ} \mathrm{C}$. The assays were repeated in triplicates and the diameters of the resultant inhibition zones were measured $( \pm 1 \mathrm{~mm})$ along two perpendicular axes and then averaged to obtain the zone of inhibition. A 'blank' was run with solvent alone, to ensure the solvent made no contribution to the zone of inhibition. The relative potency was estimated by reference to standards prepared with cephalosporin C.

\section{(5R)-5-Methoxycarbonyl-2-(pyridin-2-yl)-1,3-thiazolidine, 2a}

Yield (1.95 g, 75\%); orange oil; inseparable 1.2 : 1 cis and trans diastereomers; $R_{\mathrm{f}}=0.44$ (petrol : EtOAc; 1 : 4); $v_{\max } / \mathrm{cm}^{-1} 1740$ (s, C=O), $3291(\mathrm{br}, \mathrm{N}-\mathrm{H}) ;{ }^{1} \mathrm{H}$ NMR $\left(\mathrm{CDCl}_{3}, 500 \mathrm{MHz}\right)$ : major isomer (cis): $\delta 8.62\left(\mathrm{~d}, 1 \mathrm{H}, J=4.8 \mathrm{~Hz}, \mathrm{H} 6^{\prime}\right), 7.67\left(\mathrm{dd}, 1 \mathrm{H}, J=7.7,1.8 \mathrm{~Hz}, \mathrm{H} 4^{\prime}\right), 7.29\left(\mathrm{~d}, 1 \mathrm{H}, J=7.8 \mathrm{~Hz}, \mathrm{H} 3^{\prime}\right), 7.20-$ $7.27\left(\mathrm{~m}, 1 \mathrm{H}, \mathrm{H} 5^{\prime}\right), 5.65(\mathrm{~s}, 1 \mathrm{H}, \mathrm{H} 2), 4.03(\mathrm{dd}, 1 \mathrm{H}, \mathrm{J}=9.7,6.7 \mathrm{~Hz}, \mathrm{H} 5), 3.82\left(\mathrm{~s}, 3 \mathrm{H}, \mathrm{CO}_{2} \mathrm{CH}_{3}\right), 3.44(\mathrm{dd}$, $\left.1 \mathrm{H}, J=10.1,6.6 \mathrm{~Hz}, \mathrm{H} 4_{\mathrm{B}}\right), 3.09\left(\operatorname{app~t}, 1 \mathrm{H}, J=9.9 \mathrm{~Hz}, \mathrm{H}_{\mathrm{A}}\right)$; minor isomer (trans): $\delta 8.57(\mathrm{~d}, 1 \mathrm{H}, J=$ $\left.4.8 \mathrm{~Hz}, H 6^{\prime}\right), 7.63-7.66\left(\mathrm{~m}, 1 \mathrm{H}, \mathrm{H} 4^{\prime}\right), 7.33\left(\mathrm{~d}, 1 \mathrm{H}, J=7.8 \mathrm{~Hz}, \mathrm{H} 3^{\prime}\right), 7.16-7.23\left(\mathrm{~m}, 1 \mathrm{H}, \mathrm{H} 5^{\prime}\right), 5.84(\mathrm{~s}$, 
$1 \mathrm{H}, \mathrm{H} 2), 4.55(\mathrm{dd}, 1 \mathrm{H}, J=6.6,4.4 \mathrm{~Hz}, \mathrm{H} 5), 3.80\left(\mathrm{~s}, 3 \mathrm{H}, \mathrm{CO}_{2} \mathrm{CH}_{3}\right), 3.32-3.40\left(\mathrm{~m}, 2 \mathrm{H}, \mathrm{H} 4{ }_{\mathrm{A}}\right.$ and $\left.\mathrm{H} 4 \mathrm{~B}\right)$;

${ }^{13} \mathrm{C} \mathrm{NMR}\left(\mathrm{CDCl}_{3}, 101 \mathrm{MHz}\right)$ : major isomer (cis): $\delta 170.8\left(\mathrm{CO}_{2} \mathrm{CH}_{3}\right), 156.4\left(\mathrm{C2}^{\prime}\right), 149.4\left(\mathrm{C6}^{\prime}\right), 136.5$ (C4'), $123.0\left(\mathrm{C3}^{\prime}\right), 121.7\left(\mathrm{C5}^{\prime}\right), 71.2(\mathrm{C} 5), 65.8(\mathrm{C} 2), 52.2\left(\mathrm{CO}_{2} \mathrm{CH}_{3}\right), 39.0$ (C4); minor isomer (trans): $\delta$ 171.8 $\left(\mathrm{CO}_{2} \mathrm{CH}_{3}\right), 158.3\left(\mathrm{C} 2^{\prime}\right), 149.2\left(\mathrm{C}^{\prime}\right), 136.5\left(\mathrm{C}^{\prime}\right), 122.6\left(\mathrm{C}^{\prime}\right), 121.2\left(\mathrm{C} 3^{\prime}\right), 70.7$ (C5), $65.3(\mathrm{C} 2)$, $52.2\left(\mathrm{CO}_{2} \mathrm{CH}_{3}\right), 38.4(\mathrm{C} 4) ; \mathrm{m} / \mathrm{z}\left(\mathrm{ESI}^{+}\right) 225\left([\mathrm{M}+\mathrm{H}]^{+}, 100 \%\right) ; \mathrm{HRMS}\left(\mathrm{ESI}^{+}\right) \mathrm{m} / \mathrm{z}:[\mathrm{M}+\mathrm{H}]^{+}$Calcd for $\mathrm{C}_{10} \mathrm{H}_{13} \mathrm{O}_{2} \mathrm{~N}_{2} \mathrm{~S} 225.0692 ;$ Found 225.0690 .

\section{(5R)-2-(2-Bromopyridin-4-yl)-5-methoxycarbonyl-1,3-thiazolidine, 2b}

Yield (3.04 g, 86\%); yellow oil; inseparable $0.6: 1$ cis and trans diastereomers; $R_{\mathrm{f}}=0.15$ (petrol : EtOAc; 4 : 1); $v_{\max } / \mathrm{cm}^{-1}$ (neat) 1736 (s, C=O), 3315 (br, N-H); ${ }^{1} \mathrm{H}$ NMR $\left(\mathrm{CDCl}_{3}, 400 \mathrm{MHz}\right)$ : major isomer (trans): $\delta 8.29\left(\mathrm{~d}, 1 \mathrm{H}, J=5.2 \mathrm{~Hz}, \mathrm{H} 6^{\prime}\right), 7.61\left(\mathrm{~s}, 1 \mathrm{H}, \mathrm{H} 3^{\prime}\right), 7.32\left(\mathrm{~d}, 1 \mathrm{H}, J=5.2 \mathrm{~Hz}, \mathrm{H} 5^{\prime}\right), 5.75(\mathrm{~s}$, $1 \mathrm{H}, \mathrm{H} 2), 3.99(\mathrm{q}, 1 \mathrm{H}, J=8.1,7.1 \mathrm{~Hz}, \mathrm{H} 5), 3.81\left(\mathrm{~s}, 3 \mathrm{H}, \mathrm{CO}_{2} \mathrm{CH}_{3}\right), 3.35(\mathrm{dd}, 1 \mathrm{H}, J=10.6,6.8 \mathrm{~Hz}, \mathrm{H} 4 \mathrm{~B})$, $3.04-3.16\left(\mathrm{~m}, 1 \mathrm{H}, \mathrm{H} 4_{\mathrm{A}}\right)$; minor isomer (cis): $\delta 8.37\left(\mathrm{~d}, 1 \mathrm{H}, J=5.2 \mathrm{~Hz}, \mathrm{H} 6^{\prime}\right), 7.65\left(\mathrm{~s}, 1 \mathrm{H}, \mathrm{H} 3^{\prime}\right), 7.38(\mathrm{~d}$, $\left.1 \mathrm{H}, J=5.2 \mathrm{~Hz}, \mathrm{H} 5^{\prime}\right), 5.47(\mathrm{~s}, 1 \mathrm{H}, \mathrm{H} 2), 3.99(\mathrm{q}, 1 \mathrm{H}, J=8.1,7.1 \mathrm{~Hz}, \mathrm{H} 5), 3.81\left(\mathrm{~s}, 3 \mathrm{H}, \mathrm{CO}_{2} \mathrm{CH}_{3}\right), 3.46(\mathrm{dd}$, $\left.1 \mathrm{H}, J=10.2,6.8 \mathrm{~Hz}, \mathrm{H} 4_{\mathrm{B}}\right), 3.04-3.16\left(\mathrm{~m}, 1 \mathrm{H}, \mathrm{H} 4_{\mathrm{A}}\right) ;{ }^{13} \mathrm{C} \mathrm{NMR}\left(\mathrm{CDCl}_{3}, 101 \mathrm{MHz}\right)$ : major isomer (trans): $\delta 171.6\left(\mathrm{CO}_{2} \mathrm{CH}_{3}\right), 154.7\left(\mathrm{C}^{\prime}\right), 150.0\left(\mathrm{C}^{\prime}\right), 142.3\left(\mathrm{C} 2^{\prime}\right), 125.7\left(\mathrm{C} 3^{\prime}\right), 121.0\left(\mathrm{C}^{\prime}\right), 68.0$ (C5), 64.0 (C2), $52.7\left(\mathrm{CO}_{2} \mathrm{CH}_{3}\right), 38.1$ (C4); minor isomer (cis): $\delta 171.0\left(\mathrm{CO}_{2} \mathrm{CH}_{3}\right), 150.6\left(\mathrm{C6}^{\prime}\right), 150.3\left(\mathrm{C}^{\prime}\right)$, $142.4\left(\mathrm{C2}^{\prime}\right), 126.5\left(\mathrm{C} 3^{\prime}\right), 121.5\left(\mathrm{C}^{\prime}\right), 69.6$ (C5), 65.4 (C2), $52.7\left(\mathrm{CO}_{2} \mathrm{CH}_{3}\right), 38.7(\mathrm{C} 4) ; \mathrm{m} / \mathrm{z}\left(\mathrm{ESI}^{+}\right) 303$ and $305\left([\mathrm{M}+\mathrm{H}]^{+}, 100 \%\right) ; \mathrm{HRMS}\left(\mathrm{ESI}{ }^{+}\right) \mathrm{m} / z:[\mathrm{M}+\mathrm{H}]^{+}$Calcd for $\mathrm{C}_{10} \mathrm{H}_{12} \mathrm{O}_{2} \mathrm{~N}_{2} \mathrm{BrS} 302.9797$ and 304.9777 ; Found 302.9795 and 304.9772.

\section{(5R)-2-(5-Bromopyridin-2-yl)-5-methoxycarbonyl-1,3-thiazolidine, 2c}

Yield (2.83 g, 80\%); yellow oil; inseparable $1: 1$ cis and trans diastereomers; $R_{\mathrm{f}}=0.31$ (petrol : EtOAc; $3: 1) ; v_{\max } / \mathrm{cm}^{-1} 1736$ (s, C=O), $3301(\mathrm{br}, \mathrm{N}-\mathrm{H}) ;{ }^{1} \mathrm{H}$ NMR $\left(\mathrm{CDCl}_{3}, 400 \mathrm{MHz}\right):$ trans isomer: $\delta$ 
$8.60\left(\mathrm{~d}, 1 \mathrm{H}, J=2.2 \mathrm{~Hz}, \mathrm{H} 6^{\prime}\right), 7.77\left(\mathrm{td}, 1 \mathrm{H}, J=8.2,2.3 \mathrm{~Hz}, \mathrm{H} 4^{\prime}\right), 7.20\left(\mathrm{~d}, 1 \mathrm{H}, J=8.0 \mathrm{~Hz}, \mathrm{H} 3^{\prime}\right), 5.80$ (s, $1 \mathrm{H}, \mathrm{H} 2), 4.47(\mathrm{dd}, 1 \mathrm{H}, J=6.7,4.7 \mathrm{~Hz}, \mathrm{H} 5), 3.79\left(\mathrm{~s}, 3 \mathrm{H}, \mathrm{CO}_{2} \mathrm{CH}_{3}\right), 3.42(\mathrm{dd}, 1 \mathrm{H}, J=10.1,6.6 \mathrm{~Hz}, \mathrm{H} 4 \mathrm{~B})$, $3.28\left(\mathrm{dd}, 1 \mathrm{H}, J=10.6,4.7 \mathrm{~Hz}, \mathrm{H} 4_{\mathrm{A}}\right)$; cis isomer: $\delta 8.66\left(\mathrm{~d}, 1 \mathrm{H}, J=2.2 \mathrm{~Hz}, \mathrm{H} 6^{\prime}\right), 7.77(\mathrm{td}, 1 \mathrm{H}, J=8.2$, $2.3 \mathrm{~Hz}, \mathrm{H} 4^{\prime}$ ), 7.25 (d, 1H, J = 8.3 Hz, H3'), 5.60 (s, 1H, H2), 4.01 (dd, $1 \mathrm{H}, J=9.6,6.6 \mathrm{~Hz}, \mathrm{H} 5$ ), 3.81 (s, $\left.3 \mathrm{H}, \mathrm{CO}_{2} \mathrm{CH}_{3}\right), 3.35(\mathrm{dd}, 1 \mathrm{H}, J=10.6,6.8 \mathrm{~Hz}, \mathrm{H} 4 \mathrm{~B}), 3.02-3.09\left(\mathrm{~m}, 1 \mathrm{H}, \mathrm{H} 4_{\mathrm{A}}\right) ;{ }^{13} \mathrm{C} \mathrm{NMR}\left(\mathrm{CDCl}_{3}, 101\right.$ $\mathrm{MHz})$ : cis and trans isomers: $\delta$ 172.0, $171.1\left(\mathrm{CO}_{2} \mathrm{CH}_{3}\right), 157.8,155.5\left(\mathrm{C2}^{\prime}\right), 151.0,150.7\left(\mathrm{C}^{\prime}\right), 139.4$ (C4'), 123.3, 122.6 (C3'), 120.2, 119.7 (C5'), 70.9, 70.4 (C5), 66.3, $65.6(\mathrm{C} 2), 52.7\left(\mathrm{CO}_{2} \mathrm{CH}_{3}\right)$, 39.5, 38.8 (C4); $m / z\left(\mathrm{ESI}^{+}\right) 303$ and $\left.305\left([\mathrm{M}+\mathrm{H}]^{+}, 100 \%\right) ; \mathrm{HRMS}(\mathrm{ESI})^{+}\right) \mathrm{m} / z:[\mathrm{M}+\mathrm{H}]^{+}$Calcd for $\mathrm{C}_{10} \mathrm{H}_{12} \mathrm{O}_{2} \mathrm{~N}_{2} \mathrm{BrS} 302.9797$ and 304.9777; Found 302.9800 and 304.9777.

\section{(5R)-2-(6-Chloropyridin-3-yl)-5-methoxycarbonyl-1,3-thiazolidine, 2d}

Yield (2.49 g, 83\%); yellow oil; inseparable $0.8: 1$ cis and trans diastereomers; $R_{\mathrm{f}}=0.48$ (petrol :

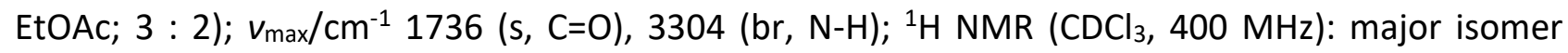
(trans): $\delta 8.43\left(\mathrm{~s}, 1 \mathrm{H}, \mathrm{H} 2^{\prime}\right), 7.73\left(\mathrm{~d}, 1 \mathrm{H}, J=8.3 \mathrm{~Hz}, \mathrm{H} 4^{\prime}\right), 7.23\left(\mathrm{~d}, 1 \mathrm{H}, J=8.2 \mathrm{~Hz}, \mathrm{H} 5^{\prime}\right), 5.77(\mathrm{~s}, 1 \mathrm{H}, \mathrm{H} 2)$, $4.02($ app t, $1 \mathrm{H}, J=6.7 \mathrm{~Hz}, \mathrm{H} 5), 3.75\left(\mathrm{~s}, 3 \mathrm{H}, \mathrm{CO}_{2} \mathrm{CH}_{3}\right.$ ), 3.32 (dd, $1 \mathrm{H}, J=11.4,7.0 \mathrm{~Hz}, \mathrm{H} 4_{\mathrm{B}}$ ), $3.03-3.15$ (m, 1H, H4 $4_{A}$ ); minor isomer (cis): $\delta 8.45\left(\mathrm{~s}, 1 \mathrm{H}, \mathrm{H} 2^{\prime}\right), 7.82\left(\mathrm{~d}, 1 \mathrm{H}, J=8.3 \mathrm{~Hz}, \mathrm{H} 4^{\prime}\right), 7.30(\mathrm{~d}, 1 \mathrm{H}, J=8.3$ $\left.\mathrm{Hz}, \mathrm{H} 5^{\prime}\right), 5.48\left(\mathrm{~s}, 1 \mathrm{H}, \mathrm{H} 2\right.$ ), $3.96(\operatorname{appt}, 1 \mathrm{H}, J=8.1 \mathrm{~Hz}, \mathrm{H} 5), 3.75\left(\mathrm{~s}, 3 \mathrm{H}, \mathrm{CO}_{2} \mathrm{CH}_{3}\right), 3.43$ (dd, $1 \mathrm{H}, J=10.1$, $\left.7.2 \mathrm{~Hz}, \mathrm{H} 4_{\mathrm{B}}\right), 3.03-3.15\left(\mathrm{~m}, 1 \mathrm{H}, \mathrm{H} 4_{\mathrm{A}}\right) ;{ }^{13} \mathrm{C} \mathrm{NMR}\left(\mathrm{CDCl}_{3}, 101 \mathrm{MHz}\right):$ major isomer (trans): $\delta 171.8$ $\left(\mathrm{CO}_{2} \mathrm{CH}_{3}\right), 150.6\left(\mathrm{C2}^{\prime}\right), 148.5\left(\mathrm{C6}^{\prime}\right), 137.8\left(\mathrm{C4}^{\prime}\right), 136.6\left(\mathrm{C3}^{\prime}\right), 123.8\left(\mathrm{C}^{\prime}\right), 67.3(\mathrm{C} 5), 64.0(\mathrm{C} 2), 52.8$ $\left(\mathrm{CO}_{2} \mathrm{CH}_{3}\right), 38.0$ (C4); minor isomer (cis): $\delta 171.3\left(\mathrm{CO}_{2} \mathrm{CH}_{3}\right), 151.6\left(\mathrm{C} 2^{\prime}\right), 149.0\left(\mathrm{C6}^{\prime}\right), 138.1\left(\mathrm{C4}^{\prime}\right)$, $133.2\left(\mathrm{C3}^{\prime}\right), 124.3\left(\mathrm{C}^{\prime}\right), 68.9(\mathrm{C} 5), 65.5(\mathrm{C} 2), 52.8\left(\mathrm{CO}_{2} \mathrm{CH}_{3}\right), 39.1(\mathrm{C} 4) ; \mathrm{m} / \mathrm{z}\left(\mathrm{ESI}^{+}\right) 259\left([\mathrm{M}+\mathrm{H}]^{+}, 100 \%\right)$ and $261\left([\mathrm{M}+\mathrm{H}]^{+}, 33 \%\right) ; \mathrm{HRMS}\left(\mathrm{ESI}^{+}\right) \mathrm{m} / \mathrm{z}:[\mathrm{M}+\mathrm{H}]^{+}$Calcd for $\mathrm{C}_{10} \mathrm{H}_{12} \mathrm{O}_{2} \mathrm{~N}_{2} \mathrm{ClS} 259.0303$ and 261.0273; Found 259.0303 and 261.0271. 
(5R)-1-(3-Ethoxy-3-oxopropanoyl)-5-methoxycarbonyl-2-(pyridin-2-yl)-1,3-thiazolidine, 3a

Yield (2.41 g, 84\%); yellow oil; separable 1.2 : 1 cis and trans diastereomers; major isomer (cis, a 1 : 0.2 mixture of rotamers in $\left.\mathrm{CDCl}_{3}\right): R_{\mathrm{f}}=0.36$ (petrol : EtOAc; $\left.1: 1\right) ;[\alpha]_{\mathrm{D}}^{25}=+67.7\left(c=0.94, \mathrm{CHCl}_{3}\right)$; $v_{\max } / \mathrm{cm}^{-1} 1664$ (s, C=O), 1740 (s, C=O); ${ }^{1} \mathrm{H}$ NMR ( $\left.\mathrm{CDCl}_{3}, 500 \mathrm{MHz}\right): \delta 8.55$ (d, $1 \mathrm{H}, J=4.8 \mathrm{~Hz}, \mathrm{H}^{\prime}$ major rotamer), $8.47\left(\mathrm{~d}, 1 \mathrm{H}, J=4.4 \mathrm{~Hz}, \mathrm{H} 6^{\prime}\right.$ minor rotamer), 8.08 (app d, $1 \mathrm{H}, J=7.9 \mathrm{~Hz}, \mathrm{H} 4^{\prime}$ major rotamer), $7.71-7.79\left(\mathrm{~m}, 1 \mathrm{H}, \mathrm{H3} 3^{\prime}\right.$ major rotamer), $7.59-7.63\left(\mathrm{~m}, 1 \mathrm{H}, \mathrm{H} 3^{\prime}\right.$ minor rotamer), 7.23 (dd, $1 \mathrm{H}, J=8.1,5.3 \mathrm{~Hz}, \mathrm{H} 5^{\prime}$ major rotamer), $7.10-7.14\left(\mathrm{~m}, 1 \mathrm{H}, \mathrm{H} 5^{\prime}\right.$ minor rotamer), $6.45(\mathrm{~s}, 1 \mathrm{H}, \mathrm{H} 2$ minor rotamer), $6.18(\mathrm{~s}, 1 \mathrm{H}, \mathrm{H} 2$ major rotamer), 5.07 (dd, $1 \mathrm{H}, J=6.7,3.7 \mathrm{~Hz}, \mathrm{H} 5$ minor rotamer), $5.01\left(\mathrm{dd}, 1 \mathrm{H}, J=8.3,6.6 \mathrm{~Hz}, \mathrm{H} 5\right.$ major rotamer), $4.18\left(\mathrm{q}, 2 \mathrm{H}, J=7.2 \mathrm{~Hz}, \mathrm{OCH}_{2} \mathrm{CH}_{3}\right.$ minor rotamer), $4.11\left(\mathrm{q}, 2 \mathrm{H}, J=7.1 \mathrm{~Hz}, \mathrm{OCH}_{2} \mathrm{CH}_{3}\right.$ major rotamer), $3.80\left(\mathrm{~s}, 3 \mathrm{H}, \mathrm{CO}_{2} \mathrm{CH}_{3}\right.$ major rotamer), $3.78(\mathrm{~s}, 3 \mathrm{H}$, $\mathrm{CO}_{2} \mathrm{CH}_{3}$ minor rotamer), $3.37\left(\mathrm{~d}, 1 \mathrm{H}, J=15.6 \mathrm{~Hz}, \mathrm{H} 2{ }^{\prime \prime}{ }_{B}\right.$ major rotamer), 3.30 (dd, $1 \mathrm{H}, J=12.0,6.6 \mathrm{~Hz}$, $\mathrm{H} 4_{\mathrm{B}}$ major rotamer), $3.22\left(\mathrm{dd}, 1 \mathrm{H}, J=12.0,8.3 \mathrm{~Hz}, \mathrm{H} 4_{\mathrm{A}}\right.$ major rotamer), $3.13(\mathrm{~d}, 1 \mathrm{H}, J=15.6 \mathrm{~Hz}$, $\mathrm{H} 2^{\prime \prime}{ }_{\mathrm{A}}$ major rotamer), $1.26\left(\mathrm{t}, 3 \mathrm{H}, J=7.1 \mathrm{~Hz}, \mathrm{OCH}_{2} \mathrm{CH}_{3}\right.$ minor rotamer), $1.21(\mathrm{t}, 3 \mathrm{H}, J=7.1 \mathrm{~Hz}$, $\mathrm{OCH}_{2} \mathrm{CH}_{3}$ major rotamer); ${ }^{13} \mathrm{C} \mathrm{NMR}\left(\mathrm{CDCl}_{3}, 101 \mathrm{MHz}\right): \delta 170.5$ and $170.1\left(\mathrm{CO}_{2} \mathrm{CH}_{3}\right), 167.0$ and 166.4 (C3"), 165.6 and 165.1 (C1'), 159.3 and 158.5 (C2'), 149.7 and 149.1 (C6'), 137.7 and 136.8 (C4'), 123.3 and $122.7\left(\mathrm{C}^{\prime}\right), 120.7$ and 120.4 (C5'), 67.7 and 67.6 (C5), 64.8 and 63.9 (C2), 61.8 and 61.7 $\left(\mathrm{OCH}_{2} \mathrm{CH}_{3}\right), 53.2$ and $52.8\left(\mathrm{CO}_{2} \mathrm{CH}_{3}\right), 42.8$ and $42.1\left(\mathrm{C2}^{\prime \prime}\right), 31.8(\mathrm{C} 4), 14.1$ and $14.1\left(\mathrm{OCH}_{2} \mathrm{CH}_{3}\right) ; \mathrm{m} / \mathrm{z}$ $\left(\mathrm{ESI}^{+}\right) 339\left([\mathrm{M}+\mathrm{H}]^{+}, 100 \%\right)$; HRMS $\left(\mathrm{ESI}^{+}\right) \mathrm{m} / \mathrm{z}:[\mathrm{M}+\mathrm{H}]^{+}$Calcd for $\mathrm{C}_{15} \mathrm{H}_{19} \mathrm{O}_{5} \mathrm{~N}_{2} \mathrm{~S}$ 339.1009; Found 339.1008

Minor isomer (trans, a $1: 0.7$ mixture of rotamers in $\mathrm{CDCl}_{3}$ ): $R_{\mathrm{f}}=0.27$ (petrol : EtOAc; $1: 1$ ); $[\alpha]_{\mathrm{D}}^{25}=$ $-117.3\left(c=0.99, \mathrm{CHCl}_{3}\right) ; v_{\max } / \mathrm{cm}^{-1} 1661(\mathrm{~s}, \mathrm{C}=0), 1739(\mathrm{~s}, \mathrm{C}=0) ;{ }^{1} \mathrm{H} \mathrm{NMR}\left(\mathrm{CDCl}_{3}, 400 \mathrm{MHz}\right): \delta 8.57(\mathrm{~d}$, $1 \mathrm{H}, J=4.1 \mathrm{~Hz}, \mathrm{H} 6^{\prime}$ major rotamer), $8.51\left(\mathrm{~d}, 1 \mathrm{H}, J=4.6 \mathrm{~Hz}, \mathrm{H} 6^{\prime}\right.$ minor rotamer), $7.72(\mathrm{td}, 1 \mathrm{H}, J=7.7$, $1.8 \mathrm{~Hz}, \mathrm{H} 4^{\prime}$ major rotamer), 7.64 (app td, $1 \mathrm{H}, J=7.6,1.4 \mathrm{~Hz}, \mathrm{H} 4^{\prime}$ minor rotamer), 7.29 (d, $1 \mathrm{H}, J=$ $7.8 \mathrm{~Hz}, \mathrm{H} 3^{\prime}$ major rotamer), $7.23\left(\mathrm{~d}, 1 \mathrm{H}, J=7.6 \mathrm{~Hz}, \mathrm{H3}^{\prime}\right.$ minor rotamer), $7.22-7.26(\mathrm{~m}, 1 \mathrm{H}$, obscured, $\mathrm{H}^{\prime}$ ' major rotamer), $7.16\left(\mathrm{dd}, 1 \mathrm{H}, J=7.4,5.0 \mathrm{~Hz}, \mathrm{H} 5^{\prime}\right.$ minor rotamer), 6.25 (s, $1 \mathrm{H}, \mathrm{H} 2$ 
minor rotamer), 6.16 (s, 1H, H2 major rotamer), 5.32 (app d, 1H, J = $7.1 \mathrm{~Hz}, \mathrm{H} 5$ major rotamer), $5.18\left(\right.$ app d, $1 \mathrm{H}, J=6.1 \mathrm{~Hz}, \mathrm{H} 5$ minor rotamer), $4.15-4.22\left(\mathrm{~m}, 2 \mathrm{H}, \mathrm{OCH}_{2} \mathrm{CH}_{3}\right.$ minor rotamer), 4.09 (q, $2 \mathrm{H}, J=7.1 \mathrm{~Hz}, \mathrm{OCH}_{2} \mathrm{CH}_{3}$ major rotamer), $3.86\left(\mathrm{~s}, 3 \mathrm{H}, \mathrm{CO}_{2} \mathrm{CH}_{3}\right.$ minor rotamer), 3.80 (s, 3H, $\mathrm{CO}_{2} \mathrm{CH}_{3}$ major rotamer), $3.83-3.89$ (dd, $1 \mathrm{H}$, obscured, $\mathrm{H}_{\mathrm{B}}$ minor rotamer), 3.60 (dd, $1 \mathrm{H}, J=12.3$, $7.2 \mathrm{~Hz}, \mathrm{H} 4_{B}$ major rotamer), $3.39-3.45\left(\mathrm{~m}, 3 \mathrm{H}, \mathrm{H} 4_{\mathrm{A}}, \mathrm{H} 2{ }^{\prime \prime}{ }_{\mathrm{A}}, \mathrm{H} 2{ }^{\prime \prime}{ }_{B}\right.$ minor rotamer), 3.32 (d, $1 \mathrm{H}, J=$ 15.2 Hz, H2" ${ }_{\text {B }}$ major rotamer), 3.20 (app d, $1 \mathrm{H}, J=12.4 \mathrm{~Hz}, \mathrm{H} 4_{\mathrm{A}}$ major rotamer), 3.07 (d, $1 \mathrm{H}, J=$ 15.2 Hz, H2" ${ }_{A}$ major rotamer), $1.26\left(\mathrm{t}, 3 \mathrm{H}, J=7.2 \mathrm{~Hz}, \mathrm{OCH}_{2} \mathrm{CH}_{3}\right.$ minor rotamer), $1.22(\mathrm{t}, 3 \mathrm{H}, J=7.2$ $\mathrm{Hz}, \mathrm{OCH}_{2} \mathrm{CH}_{3}$ major rotamer); ${ }^{13} \mathrm{C} \mathrm{NMR}\left(\mathrm{CDCl}_{3}, 101 \mathrm{MHz}\right): \delta 170.4$ and $169.8\left(\mathrm{CO}_{2} \mathrm{CH}_{3}\right), 167.1$ and $166.4\left(\mathrm{C} 3^{\prime \prime}\right), 165.1$ and $164.7\left(\mathrm{C}^{\prime \prime}\right), 160.4$ and $160.2\left(\mathrm{C} 2^{\prime}\right), 150.1$ and $149.6\left(\mathrm{C}^{\prime}\right), 137.5$ and 136.8 (C4'), 123.3 and 122.7 (C3'), 119.8 and $119.5\left(\mathrm{C5}^{\prime}\right), 66.7$ and 66.2 (C5), 64.2 and 64.0 (C2), 61.8 and $61.6\left(\mathrm{OCH}_{2} \mathrm{CH}_{3}\right), 53.5$ and $52.9\left(\mathrm{CO}_{2} \mathrm{CH}_{3}\right), 43.3$ and $42.5\left(\mathrm{C}{ }^{\prime \prime}\right), 31.5(\mathrm{C} 4), 14.1$ and $14.1\left(\mathrm{OCH}_{2} \mathrm{CH}_{3}\right)$; $m / z\left(\mathrm{ESI}^{+}\right) 339\left([\mathrm{M}+\mathrm{H}]^{+}, 100 \%\right) ; \mathrm{HRMS}\left(\mathrm{ESI}^{+}\right) \mathrm{m} / \mathrm{z}:[\mathrm{M}+\mathrm{Na}]^{+}$Calcd for $\mathrm{C}_{15} \mathrm{H}_{18} \mathrm{O}_{5} \mathrm{~N}_{2} \mathrm{NaS} 361.0829$; Found 361.0826 .

\section{(5R)-2-(2-Bromopyridin-4-yl)-1-(3-ethoxy-3-oxopropanoyl)-5-methoxycarbonyl-1,3-thiazolidine,}

\section{$3 b$}

Yield (3.80 g, 92\%); yellow oil; inseparable $1.6: 1$ cis and trans diastereomers; $R_{\mathrm{f}}=0.33$ (petrol : EtOAc; $1: 1) ; v_{\max } / \mathrm{cm}^{-1} 1661$ (s, C=O), $1738(\mathrm{~s}, \mathrm{C}=0) ;{ }^{1} \mathrm{H} \mathrm{NMR}\left(\mathrm{CDCl}_{3}, 400 \mathrm{MHz}\right)$ : cis isomer as a 1 : 0.3 mixture of rotamers, trans isomer $1: 0.8$ as a mixture of rotamers in $\mathrm{CDCl}_{3}: \delta 8.39$ (app t, $1 \mathrm{H}, J$ $=4.8 \mathrm{~Hz}, \mathrm{H} 6^{\prime}$ trans isomer), $8.30\left(\mathrm{~d}, 1 \mathrm{H}, \mathrm{J}=5.2 \mathrm{~Hz}, \mathrm{H} 6^{\prime}\right.$ cis isomer), 7.39 (s, 1H, H3' cis isomer), 7.34 (s, $1 \mathrm{H}, \mathrm{H} 3^{\prime}$ trans isomer), $7.18\left(\mathrm{~d}, 1 \mathrm{H}, \mathrm{J}=6.7 \mathrm{~Hz}, \mathrm{H} 5^{\prime}\right.$ cis isomer), $7.12\left(\mathrm{~d}, 1 \mathrm{H}, \mathrm{J}=6.5 \mathrm{~Hz}, \mathrm{H} 5^{\prime}\right.$ trans isomer), 6.22 (s, 1H, H2 cis isomer minor rotamer), 6.14 (s, 1H, H2 cis isomer major rotamer), 6.12 (s, 1H, H2 trans isomer major rotamer), $6.12(\mathrm{~s}, 1 \mathrm{H}, \mathrm{H} 2$ trans isomer minor rotamer), 5.20 (app t, $1 \mathrm{H}, J=3.4 \mathrm{~Hz}, \mathrm{H} 5$ cis isomer major rotamer), $4.19-4.28\left(\mathrm{~m}, 2 \mathrm{H}, \mathrm{OCH}_{2} \mathrm{CH}_{3}\right.$ cis isomer), $4.08-4.19$ (m, $2 \mathrm{H}, \mathrm{OCH}_{2} \mathrm{CH}_{3}$ trans isomer), $3.86\left(\mathrm{~s}, 3 \mathrm{H}, \mathrm{CO}_{2} \mathrm{CH}_{3}\right.$ cis isomer, minor rotamer), $3.76\left(\mathrm{~s}, 3 \mathrm{H}, \mathrm{CO}_{2} \mathrm{CH}_{3}\right.$ 
trans isomer, minor rotamer), 3,74 (s, $3 \mathrm{H}, \mathrm{CO}_{2} \mathrm{CH}_{3}$ cis isomer, major rotamer), $3.72\left(\mathrm{~s}, 3 \mathrm{H}, \mathrm{CO}_{2} \mathrm{CH}_{3}\right.$ trans isomer, major rotamer), $3.72-3.79\left(\mathrm{~m}, 2 \mathrm{H}\right.$, obscured, $\left.\mathrm{H}_{\mathrm{B}}\right), 3.44-3.50\left(\mathrm{~m}, 2 \mathrm{H}, \mathrm{H} 4_{\mathrm{A}}\right), 3.12-$ $3.39\left(\mathrm{~m}, 4 \mathrm{H}, \mathrm{H}{ }^{\prime \prime}{ }_{\mathrm{A}}, \mathrm{H}{ }^{\prime \prime}{ }_{B}\right), 1.31\left(\mathrm{t}, 3 \mathrm{H}, \mathrm{J}=7.0 \mathrm{~Hz}, \mathrm{OCH}_{2} \mathrm{CH}_{3}\right.$, trans isomer major rotamer), $1.22-1.28$ (m, 3H, $\mathrm{OCH}_{2} \mathrm{CH}_{3}$, cis isomer major rotamer); ${ }^{13} \mathrm{C} \mathrm{NMR}\left(\mathrm{CDCl}_{3}, 101 \mathrm{MHz}\right): \delta 169.9,169.8,169.7$, $168.9\left(\mathrm{CO}_{2} \mathrm{CH}_{3}\right.$ major, minor and rotamers), 167.2, 167.1, 166.7, 166.3 (C3" major, minor and rotamers), 165.9, 165.4, 165.1, 165.0 (C1" major, minor and rotamers), 153.9, 153.6, 152.4, 151.2 (C6' major, minor and rotamers), 150.9, 150.6, 150.2, 150.0 (C4' major, minor and rotamers), 143.0, 142.7, 142.3, 142.1 (C2' major, minor and rotamers), 125.9, 125.4, 123.9 (C3' major, minor and rotamers), 120.9, 120.3, 119.3, 119.1 (C5' major, minor and rotamers), 67.8, 67.1, 65.2, 64.7 (C5 major, minor and rotamers), 64.1, 63.9, 63.8, 63.6 (C2 major, minor and rotamers), 62.0, 61.9, 61.7, $61.4\left(\mathrm{OCH}_{2} \mathrm{CH}_{3}\right.$ major, minor and rotamers), 53.6, 53.4, 52.9, $49.0\left(\mathrm{CO}_{2} \mathrm{CH}_{3}\right.$ major, minor and rotamers), 43.0, 42.7, 42.3, 42.0 (C2" major, minor and rotamers), 34.3, 33.7, 33.2, 33.1 (C4 major, minor and rotamers), 14.1, 14.0, 14.0, $13.9\left(\mathrm{OCH}_{2} \mathrm{CH}_{3}\right.$ major, minor and rotamers); $\left.\mathrm{m} / \mathrm{z}(\mathrm{ESI})^{-}\right) 415$ and $417\left([\mathrm{M}-\mathrm{H}]^{-}, 100 \%\right)$; HRMS $\left(\mathrm{ESI}^{+}\right) \mathrm{m} / \mathrm{z}:[\mathrm{M}+\mathrm{Na}]^{+}$Calcd for $\mathrm{C}_{15} \mathrm{H}_{17} \mathrm{O}_{5} \mathrm{~N}_{2} \mathrm{BrNaS} 438.9934$ and 440.9913; Found 438.9929 and 440.9908.

(5R)-2-(5-Bromopyridin-2-yl)-1-(3-ethoxy-3-oxopropanoyl)-5-methoxycarbonyl-1,3-thiazolidine,

\section{3c}

Yield (3.28 g, 85\%); yellow oil; inseparable $1.3: 1$ cis and trans diastereomers; $R_{\mathrm{f}}=0.30$ (petrol : EtOAc; $1: 1) ; v_{\max } / \mathrm{cm}^{-1} 1662(\mathrm{~s}, \mathrm{C}=0), 1739(\mathrm{~s}, \mathrm{C}=0) ;{ }^{1} \mathrm{H} \mathrm{NMR}\left(\mathrm{CDCl}_{3}, 400 \mathrm{MHz}\right)$ : cis isomer as a 1 : 0.2 mixture of rotamers, trans isomer $1: 0.9$ as a mixture of rotamers in $\mathrm{CDCl}_{3}: \delta 8.51(\mathrm{~d}, 1 \mathrm{H}, J=$ $2.5 \mathrm{~Hz}, \mathrm{H} 6^{\prime}$ trans isomer major rotamer), $8.43\left(\mathrm{~d}, 1 \mathrm{H}, \mathrm{J}=2.5 \mathrm{~Hz}, \mathrm{H} 6^{\prime}\right.$ trans isomer minor rotamer), $8.28\left(\mathrm{~d}, 1 \mathrm{H}, J=2.6 \mathrm{~Hz}, \mathrm{H}^{\prime}\right.$ cis isomer major rotamer), $8.24\left(\mathrm{~d}, 1 \mathrm{H}, J=2.3 \mathrm{~Hz}, \mathrm{H} 6^{\prime}\right.$ cis isomer minor rotamer), $8.03\left(\mathrm{dd}, 1 \mathrm{H}, J=8.4,2.7 \mathrm{~Hz}, \mathrm{H} 4^{\prime}\right.$ trans isomer major rotamer), $7.74(\mathrm{dd}, 1 \mathrm{H}, J=8.3,2.5$ $\mathrm{Hz}, \mathrm{H} 4^{\prime}$ trans isomer minor rotamer), $7.43-7.49\left(\mathrm{~m}, 4 \mathrm{H}, \mathrm{H} 3^{\prime}\right.$ trans isomer minor and major 
rotamers, $\mathrm{H}^{\prime}$ cis isomer major and minor rotamers), $7.37\left(\mathrm{~d}, 1 \mathrm{H}, \mathrm{J}=8.2 \mathrm{~Hz}, \mathrm{H} 3^{\prime}\right.$ cis isomer major rotamer), $7.22\left(\mathrm{~d}, 1 \mathrm{H}, J=8.2 \mathrm{~Hz}, \mathrm{H} 3^{\prime}\right.$ cis isomer minor rotamer), $6.21(\mathrm{~s}, 1 \mathrm{H}, \mathrm{H} 2$ cis isomer minor rotamer), $6.19(\mathrm{~s}, 1 \mathrm{H}, \mathrm{H} 2$ cis isomer major rotamer), $6.18(\mathrm{~s}, 1 \mathrm{H}, \mathrm{H} 2$ trans isomer minor rotamer), $6.15(\mathrm{~s}, 1 \mathrm{H}, \mathrm{H} 2$ trans isomer major rotamer), 5.24 (app d, $1 \mathrm{H}, \mathrm{J}=6.3 \mathrm{~Hz}, \mathrm{H} 5$ cis isomer minor rotamer), 5.15 (app t, $1 \mathrm{H}, \mathrm{J}=3.3 \mathrm{~Hz}, \mathrm{H} 5$ cis isomer major rotamer), 5.04 (dd, $1 \mathrm{H}, J=6.2,2.6 \mathrm{~Hz}, \mathrm{H} 5$ trans isomer minor rotamer), $5.00(\mathrm{app} \mathrm{t}, 1 \mathrm{H}, J=7.1 \mathrm{~Hz}, \mathrm{H} 5$ trans isomer major rotamer), $3.97-$ $4.20\left(\mathrm{~m}, 8 \mathrm{H}, \mathrm{OCH}_{2} \mathrm{CH}_{3}\right.$ cis and trans isomers), $3.80\left(\mathrm{~s}, 3 \mathrm{H}, \mathrm{CO}_{2} \mathrm{CH}_{3}\right.$ cis isomer major rotamer), 3.78 (s, $3 \mathrm{H}, \mathrm{CO}_{2} \mathrm{CH}_{3}$ trans isomer major rotamer), $3.77\left(\mathrm{~s}, 3 \mathrm{H}, \mathrm{CO}_{2} \mathrm{CH}_{3}\right.$ trans isomer minor rotamer), $3.74(\mathrm{~s}$, $3 \mathrm{H}, \mathrm{CO}_{2} \mathrm{CH}_{3}$ cis isomer minor rotamer), $3.09-3.49\left(\mathrm{~m}, 16 \mathrm{H}, \mathrm{H}_{4}, \mathrm{H} 4_{B}, \mathrm{H} 2{ }^{\prime \prime}{ }_{A}, \mathrm{H} 2{ }^{\prime \prime}{ }_{B}\right.$ cis and trans isomers), $1.14-1.26\left(\mathrm{~m}, 12 \mathrm{H}, \mathrm{OCH}_{2} \mathrm{CH}_{3}\right.$ cis and trans isomers with rotamers); ${ }^{13} \mathrm{C} \mathrm{NMR}\left(\mathrm{CDCl}_{3}, 101\right.$ $\mathrm{MHz}): \delta 170.0,170.0,169.8,169.0\left(\mathrm{CO}_{2} \mathrm{CH}_{3}\right.$ major, minor and rotamers), 167.1, 166.8, 166.3, 165.9 (C3" major, minor and rotamers), 165.2, 165.1, 165.0, 165.0 (C1" major, minor and rotamers), 149.4, 148.4, 147.2, 146.8 (C2' major, minor and rotamers), 142.2, 142.0, 141.4, 140.7 (C6' major, minor and rotamers), 137.8, 137.3, 137.1, 137.1 (C4' major, minor and rotamers), 135.7, 135.5, 135.4, 134.1 (C3' major, minor and rotamers), 128.5, 128.3, 127.7, 127.6 (C5' major, minor and rotamers), 64.6, 64.2, 64.1, 63.9 (C5 major, minor and rotamers), 63.7, 63.3, 62.9, 62.3 (C2 major, minor and rotamers), 61.9, 61.8, 61.8, $61.7\left(\mathrm{OCH}_{2} \mathrm{CH}_{3}\right.$ major, minor and rotamers), 53.5, 53.3, 52.9, $49.0\left(\mathrm{CO}_{2} \mathrm{CH}_{3}\right.$ major, minor and rotamers), 43.0, 42.8, 42.3, 42.0 (C2" major, minor and rotamers), 34.2, 33.7, 33.2, 32.1 (C4 major, minor and rotamers), 14.1, 14.0, 14.0, $14.0\left(\mathrm{OCH}_{2} \mathrm{CH}_{3}\right.$ major, minor and rotamers); $m / z\left(\mathrm{ESI}^{+}\right) 417$ and $\left.419\left([\mathrm{M}+\mathrm{H}]^{+}, 100 \%\right) ; \mathrm{HRMS}(\mathrm{ESI})^{+}\right) \mathrm{m} / z:[\mathrm{M}+\mathrm{H}]^{+}$Calcd for $\mathrm{C}_{15} \mathrm{H}_{18} \mathrm{O}_{5} \mathrm{~N}_{2} \mathrm{BrS} 417.0114$ and 419.0094; Found 417.0109 and 419.0087.

(5R)-2-(6-Chloropyridin-3-yl)-1-(3-ethoxy-3-oxopropanoyl)-5-methoxycarbonyl-1,3-thiazolidine, 3d 
Yield (2.66 g, 77\%); yellow oil; inseparable $1.2: 1$ cis and trans diastereomers; $R_{\mathrm{f}}=0.39$ (petrol : EtOAc; $1: 1) ; v_{\max } / \mathrm{cm}^{-1} 1660$ (s, C=O), 1737 (s, C=O); ${ }^{1} \mathrm{H} \mathrm{NMR}\left(\mathrm{CDCl}_{3}, 400 \mathrm{MHz}\right)$ : cis isomer as a 1 : 0.5 mixture of rotamers, trans isomer $1: 0.9$ as a mixture of rotamers in $\mathrm{CDCl}_{3}: \delta 8.53\left(\mathrm{~s}, 1 \mathrm{H}, \mathrm{H}^{\prime}\right.$ trans isomer major rotamer), $8.46\left(\mathrm{~s}, 1 \mathrm{H}, \mathrm{H} 2^{\prime}\right.$ trans isomer minor rotamer), 8.31 (s, 1H, H2' cis isomer major rotamer), $8.27\left(\mathrm{~s}, 1 \mathrm{H}, \mathrm{H} 2^{\prime}\right.$ cis isomer minor rotamer), $8.13-8.19$ (m, $1 \mathrm{H}, \mathrm{H} 4^{\prime}$ trans isomer major rotamer), $7.85\left(\mathrm{~d}, 1 \mathrm{H}, J=10.2 \mathrm{~Hz}, \mathrm{H} 4^{\prime}\right.$ trans isomer minor rotamer), $7.58(\mathrm{~d}, 1 \mathrm{H}, J=$ 10.5 Hz, H4' cis isomer major rotamer), $7.54\left(\mathrm{~d}, 1 \mathrm{H}, J=10.5 \mathrm{~Hz}, \mathrm{H} 4^{\prime}\right.$ cis isomer minor rotamer), $7.31-7.37\left(\mathrm{~m}, 2 \mathrm{H}, \mathrm{H} 5^{\prime}\right.$ trans isomers with rotamers), $7.20-7.26\left(\mathrm{~m}, 2 \mathrm{H}, \mathrm{H} 5^{\prime}\right.$ cis isomers with rotamers), $6.23(\mathrm{~s}, 1 \mathrm{H}, \mathrm{H} 2$ cis isomer with rotamers), $6.21(\mathrm{~s}, 1 \mathrm{H}, \mathrm{H} 2$, trans isomer major rotamer), $6.17(\mathrm{~s}, 1 \mathrm{H}, \mathrm{H} 2$ trans isomer minor rotamer), 5.26 (app d, $1 \mathrm{H}, \mathrm{J}=6.7 \mathrm{~Hz}, \mathrm{H} 5$ cis isomer minor rotamer), $5.16(\operatorname{app~t}, 1 \mathrm{H}, J=2.9 \mathrm{~Hz}, \mathrm{H} 5$ cis isomer major rotamer), $5.03-5.08(\mathrm{~m}, 1 \mathrm{H}, \mathrm{H} 5$ trans isomer major rotamer), 5.01 (app d, $1 \mathrm{H}, J=7.0 \mathrm{~Hz}, \mathrm{H} 5$ trans isomer minor rotamer), $4.00-4.22$ (m, $8 \mathrm{H}, \mathrm{OCH}_{2} \mathrm{CH}_{3}$ cis and trans isomers with rotamers), $3.82\left(\mathrm{~s}, 3 \mathrm{H}, \mathrm{CO}_{2} \mathrm{CH}_{3}\right.$ cis isomer major rotamer), $3.80\left(\mathrm{~s}, 3 \mathrm{H}, \mathrm{CO}_{2} \mathrm{CH}_{3}\right.$ trans isomer minor rotamer), $3.79\left(\mathrm{~s}, 3 \mathrm{H}, \mathrm{CO}_{2} \mathrm{CH}_{3}\right.$ trans isomer major rotamer), $3.75\left(\mathrm{~s}, 3 \mathrm{H}, \mathrm{CO}_{2} \mathrm{CH}_{3}\right.$ cis isomer minor rotamer), $3.09-3.53\left(\mathrm{~m}, 16 \mathrm{H}, \mathrm{H} 4_{\mathrm{A}}, \mathrm{H} 4_{\mathrm{B}}, \mathrm{H} 2{ }^{\prime \prime}{ }_{\mathrm{A}}, \mathrm{H} 2{ }^{\prime \prime}{ }_{B}\right.$ cis and trans isomers with rotamers), $1.15-1.28\left(\mathrm{~m}, 12 \mathrm{H}, \mathrm{OCH}_{2} \mathrm{CH}_{3}\right.$ cis and trans isomers with rotamers); ${ }^{13} \mathrm{C} \mathrm{NMR}\left(\mathrm{CDCl}_{3}, 101 \mathrm{MHz}\right): \delta 170.1,170.1,169.9,169.1\left(\mathrm{CO}_{2} \mathrm{CH}_{3}\right.$ major, minor and rotamers), 167.2, 166.9, 166.4, 166.0 (C3" major, minor and rotamers), 166.0, 165.2, 165.0 (C1" major, minor and rotamers), 151.8, 151.6, 150.9, 150.4 (C2' major, minor and rotamers), 149.1, 148.1, 146.8, 146.5 (C6' major, minor and rotamers), 138.1, 137.4, 136.9, 136.8 (C4' major, minor and rotamers), 135.7, 135.7, 135.1, 133.7 (C3' major, minor and rotamers), 124.8, 124.7, 124.1, 123.9 (C5' major, minor and rotamers), 64.7, 64.3, 64.2, 64.0 (C5 major, minor and rotamers), 63.8, 63.4, 63.0, 62.3 (C2 major, minor and rotamers), 62.0, 62.0, 61.9, $61.8\left(\mathrm{OCH}_{2} \mathrm{CH}_{3}\right.$ major, minor and rotamers), 53.6, 53.4, 53.0, $49.0\left(\mathrm{CO}_{2} \mathrm{CH}_{3}\right.$ major, minor and rotamers), 43.2, 43.0, 42.4, 42.1 (C2" major, minor and rotamers), 34.3, 34.0, 33.3, 32.2 (C4 major, minor and rotamers), 14.1, 14.1, 14.0, $14.0\left(\mathrm{OCH}_{2} \mathrm{CH}_{3}\right.$ 
major, minor and rotamers); $m / z\left(\mathrm{ESI}^{+}\right) 373\left([\mathrm{M}+\mathrm{H}]^{+}, 100 \%\right)$ and $\left.375\left([\mathrm{M}+\mathrm{H}]^{+}, 33 \%\right) ; \mathrm{HRMS}(\mathrm{ESI})^{+}\right)$ $\mathrm{m} / z:[\mathrm{M}+\mathrm{H}]^{+}$Calcd for $\mathrm{C}_{15} \mathrm{H}_{18} \mathrm{O}_{5} \mathrm{~N}_{2} \mathrm{ClS} 373.0620$ and 375.0590; Found 373.0613 and 375.0582 .

\section{(2S,5R)-1-Aza-7-ethoxycarbonyl-6-hydroxy-8-oxo-2-(pyridin-2-yl)-3-thiabicyclo[3.3.0]oct-6-ene,}

\section{$4 a$}

Yield (870 mg, 48\%); brown oil; $R_{\mathrm{f}}=0.23(\mathrm{MeOH}:$ EtOAc; $1: 6) ;[\alpha]_{\mathrm{D}}^{25}=-196.7(c=0.55, \mathrm{MeOH})$; $v_{\max } / \mathrm{cm}^{-1} 1589$ (s, C=C), 1636 (s, C=O); ${ }^{1} \mathrm{H}$ NMR (methanol- $d_{4}, 500 \mathrm{MHz}$ ): $\delta$ (C6-OH not seen), 8.44 (d, $1 \mathrm{H}, J=5.6 \mathrm{~Hz}, \mathrm{H6} 6^{\prime}$ ), $7.78\left(\mathrm{app} t \mathrm{td}, 1 \mathrm{H}, J=7.7,1.8 \mathrm{~Hz}, \mathrm{H} 4^{\prime}\right), 7.47$ (d, $\left.1 \mathrm{H}, J=7.8 \mathrm{~Hz}, \mathrm{H} 3^{\prime}\right), 7.27$ (dd, $\left.1 \mathrm{H}, J=7.4,5.0 \mathrm{~Hz}, \mathrm{H5} 5^{\prime}\right), 6.36(\mathrm{~s}, 1 \mathrm{H}, \mathrm{H} 2), 4.40(\mathrm{app} \mathrm{t}, 1 \mathrm{H}, J=7.7 \mathrm{~Hz}, \mathrm{H5}), 4.11-4.27(\mathrm{~m}, 2 \mathrm{H}$, $\left.\mathrm{OCH}_{2} \mathrm{CH}_{3}\right), 3.24(\mathrm{dd}, 1 \mathrm{H}, J=10.8,7.3 \mathrm{~Hz}, \mathrm{H} 4 \mathrm{~B}), 2.91(\mathrm{dd}, 1 \mathrm{H}, J=10.9,8.1 \mathrm{~Hz}, \mathrm{H} 4 \mathrm{~A}), 1.28(\mathrm{t}, 3 \mathrm{H}, J=7.3$ $\mathrm{Hz}, \mathrm{OCH}_{2} \mathrm{CH}_{3}$ ); ${ }^{13} \mathrm{C}$ NMR (methanol- $d_{4}, 101 \mathrm{MHz}$ ): $\delta 194.9$ (C6), 179.5 (C8), 168.1 (C9), 162.3 (C2'), $149.8\left(\mathrm{C6}^{\prime}\right), 139.0\left(\mathrm{C} 4^{\prime}\right), 123.9\left(\mathrm{C} 3^{\prime}\right), 121.2\left(\mathrm{C} 5^{\prime}\right), 91.3(\mathrm{C} 7), 71.3(\mathrm{C} 5), 65.2(\mathrm{C} 2), 60.2\left(\mathrm{OCH}_{2} \mathrm{CH}_{3}\right)$, 34.6 (C4), $15.0\left(\mathrm{OCH}_{2} \mathrm{CH}_{3}\right) ; \mathrm{m} / \mathrm{z}\left(\mathrm{ESI}^{-}\right) 305\left([\mathrm{M}-\mathrm{H}]^{-}, 100 \%\right) ; \mathrm{HRMS}\left(\mathrm{ESI}^{+}\right) \mathrm{m} / \mathrm{z}:[\mathrm{M}+\mathrm{H}]^{+}$Calcd for $\mathrm{C}_{14} \mathrm{H}_{15} \mathrm{O}_{4} \mathrm{~N}_{2} \mathrm{~S} 307.0747$; Found 307.0747.

\section{(2S,5R)-1-Aza-2-(2-bromopyridin-4-yl)-7-ethoxycarbonyl-6-hydroxy-8-oxo-3-}

\section{thiabicyclo[3.3.0]oct-6-ene, $4 b$}

Yield $(1.20 \mathrm{~g}, 35 \%)$; orange foamy solid, $\mathrm{mp} 165-17^{\circ} \mathrm{C} ; R_{\mathrm{f}}=0.36(\mathrm{MeOH}:$ EtOAc; $1: 6) ;[\alpha]_{\mathrm{D}}^{25}=-$ $68.8\left(c=0.35, \mathrm{CHCl}_{3}\right) ; v_{\max } / \mathrm{cm}^{-1}$ (neat) $1586(\mathrm{~s}, \mathrm{C}=\mathrm{C}), 1635(\mathrm{~s}, \mathrm{C}=\mathrm{O}) ;{ }^{1} \mathrm{H}$ NMR (methanol- $d_{4}, 400$ MHz): $\delta$ (C6-OH not seen), $8.27\left(\mathrm{~d}, 1 \mathrm{H}, J=5.2 \mathrm{~Hz}, \mathrm{H} 6^{\prime}\right), 7.63\left(\mathrm{~s}, 1 \mathrm{H}, \mathrm{H} 3^{\prime}\right), 7.44\left(\mathrm{~d}, 1 \mathrm{H}, J=5.2 \mathrm{~Hz}, \mathrm{H} 5^{\prime}\right)$, $6.30(\mathrm{~s}, 1 \mathrm{H}, \mathrm{H} 2), 4.17-4.24\left(\mathrm{~m}, 3 \mathrm{H}, \mathrm{OCH}_{2} \mathrm{CH}_{3}\right.$ and $\left.\mathrm{H} 5\right), 3.21-3.25$ (dd, $1 \mathrm{H}, \mathrm{H} 4{ }_{\mathrm{B}}$ obscured by solvent peak), $2.97(\mathrm{dd}, 1 \mathrm{H}, J=11.1,7.2 \mathrm{~Hz}, \mathrm{H} 4 \mathrm{~A}), 1.26\left(\mathrm{t}, 3 \mathrm{H}, J=7.1 \mathrm{~Hz}, \mathrm{OCH}_{2} \mathrm{CH}_{3}\right) ;{ }^{13} \mathrm{C} \mathrm{NMR}$ (methanol-d4, $101 \mathrm{MHz}$ ): $\delta 194.6$ (C6), 179.7 (C8), 167.7 (C9), 156.4 (C6'), 151.2 (C4'), 142.8 (C2'), 126.7 (C3'), 122.2 (C5'), 91.5 (C7), 70.2 (C5), $63.3(\mathrm{C} 2), 60.2\left(\mathrm{OCH}_{2} \mathrm{CH}_{3}\right), 34.6(\mathrm{C} 4), 15.1\left(\mathrm{OCH}_{2} \mathrm{CH}_{3}\right)$; 
$\mathrm{m} / z\left(\mathrm{ESI}^{-}\right) 383$ and 385 ([M-H]', 100\%); HRMS (ESI $\left.{ }^{-}\right) \mathrm{m} / \mathrm{z}$ : [M-H] $]^{-}$Calcd for $\mathrm{C}_{14} \mathrm{H}_{12} \mathrm{O}_{4} \mathrm{~N}_{2} \mathrm{BrS} 382.9707$ and 384.9686; Found 382.9712 and 384.9690.

\section{(2S,5R)-1-Aza-2-(5-bromopyridin-2-yl)-7-ethoxycarbonyl-6-hydroxy-8-oxo-3-}

\section{thiabicyclo[3.3.0]oct-6-ene, 4c}

Yield (1.18 g, 40\%); brown foamy solid, $\mathrm{mp} 157-163{ }^{\circ} \mathrm{C} ; R_{\mathrm{f}}=0.26(\mathrm{MeOH}:$ EtOAc; $1: 6) ;[\alpha]_{\mathrm{D}}^{25}=-$ $129.8\left(c=1.01, \mathrm{CHCl}_{3}\right) ; v_{\max } / \mathrm{cm}^{-1}$ (neat) 1581 (s, C=C), $1638(\mathrm{~s}, \mathrm{C}=0) ;{ }^{1} \mathrm{H} \mathrm{NMR}\left(\mathrm{CDCl}_{3}, 400 \mathrm{MHz}\right): \delta$ (C6-OH not seen), $8.60\left(\mathrm{~d}, 1 \mathrm{H}, J=2.2 \mathrm{~Hz}, \mathrm{H} 6^{\prime}\right), 7.78\left(\mathrm{dd}, 1 \mathrm{H}, J=8.3,2.3 \mathrm{~Hz}, \mathrm{H} 4^{\prime}\right), 7.29(\mathrm{~d}, 1 \mathrm{H}, J=8.3$ $\left.\mathrm{Hz}, \mathrm{H3} 3^{\prime}\right), 6.29\left(\mathrm{~s}, 1 \mathrm{H}, \mathrm{H} 2\right.$ ) , $4.88(\operatorname{app~t}, 1 \mathrm{H}, J=7.7 \mathrm{~Hz}, \mathrm{H} 5), 4.36\left(\mathrm{q}, 2 \mathrm{H}, J=7.1 \mathrm{~Hz}, \mathrm{OCH}_{2} \mathrm{CH}_{3}\right.$ ), 3.37 (dd, $1 \mathrm{H}, J=10.9,7.3 \mathrm{~Hz}, \mathrm{H} 4 \mathrm{~B}), 3.01(\mathrm{dd}, 1 \mathrm{H}, J=10.9,8.1 \mathrm{~Hz}, \mathrm{H} 4 \mathrm{~A}), 1.36\left(\mathrm{t}, 3 \mathrm{H}, J=7.1 \mathrm{~Hz}, \mathrm{OCH}_{2} \mathrm{CH}_{3}\right) ;{ }^{13} \mathrm{C}$ NMR ( $\left.\mathrm{CDCl}_{3}, 101 \mathrm{MHz}\right): \delta 187.2$ (C6), 170.0 (C8), 166.9 (C9), 158.4 (C2'), 150.7 (C6'), 139.5 (C4'), 121.5 (C3'), 119.8 (C5'), 97.8 (C7), 66.4 (C5), 62.6 (C2), $61.5\left(\mathrm{OCH}_{2} \mathrm{CH}_{3}\right), 32.9$ (C4), $14.3\left(\mathrm{OCH}_{2} \mathrm{CH}_{3}\right)$; $m / z$ (ESI $\left.^{-}\right) 383$ and $385\left([\mathrm{M}-\mathrm{H}]^{-}, 100 \%\right) ; \operatorname{HRMS}\left(\mathrm{ESI}^{+}\right) \mathrm{m} / \mathrm{z}:[\mathrm{M}+\mathrm{Na}]^{+}$Calcd for $\mathrm{C}_{14} \mathrm{H}_{13} \mathrm{O}_{4} \mathrm{~N}_{2} \mathrm{BrNaS}$ 406.9672 and 408.9651; Found 406.9673 and 408.9652.

\section{(2S,5R)-1-Aza-2-(6-chloropyridin-3-yl)-7-ethoxycarbonyl-6-hydroxy-8-oxo-3-}

\section{thiabicyclo[3.3.0]oct-6-ene, 4d}

Yield (974 mg, 41\%); orange oil; $R_{\mathrm{f}}=0.36(\mathrm{MeOH}:$ EtOAc; $1: 6) ;[\alpha]_{\mathrm{D}}^{25}=-168.7\left(c=0.13, \mathrm{CHCl}_{3}\right)$; $v_{\max } / \mathrm{cm}^{-1} 1585$ (s, C=C), 1653 (s, C=O), 1704 (s, C=O); ${ }^{1} \mathrm{H}$ NMR (methanol-d4, $400 \mathrm{MHz}$ ): $\delta(\mathrm{C} 6-\mathrm{OH}$ not seen), $8.47\left(\mathrm{~s}, 1 \mathrm{H}, \mathrm{H} 2^{\prime}\right), 7.94\left(\mathrm{~d}, 1 \mathrm{H}, J=8.2 \mathrm{~Hz}, \mathrm{H} 4^{\prime}\right), 7.45\left(\mathrm{~d}, 1 \mathrm{H}, J=8.3 \mathrm{~Hz}, \mathrm{H} 5^{\prime}\right), 6.28(\mathrm{~s}, 1 \mathrm{H}, \mathrm{H} 2)$, $4.83(\operatorname{appt}, 1 \mathrm{H}, J=7.5 \mathrm{~Hz}, \mathrm{H} 5), 4.28\left(\mathrm{q}, 2 \mathrm{H}, J=7.5 \mathrm{~Hz}, \mathrm{OCH}_{2} \mathrm{CH}_{3}\right), 3.32-3.38(\mathrm{~m}, 1 \mathrm{H}, \mathrm{H} 4 \mathrm{~B}), 3.07$ (dd, $1 \mathrm{H}, J=10.9,8.3 \mathrm{~Hz}, \mathrm{H} 4 \mathrm{~A}$ ), $1.31\left(\mathrm{t}, 3 \mathrm{H}, J=7.1 \mathrm{~Hz}, \mathrm{OCH}_{2} \mathrm{CH}_{3}\right) ;$ ); ${ }^{13} \mathrm{C}$ NMR (methanol- $\left.d_{4}, 101 \mathrm{MHz}\right): \delta$ 185.5 (C6), 173.5 (C8), 164.7 (C9), 151.7 (C2'), 149.0 (C6'), 139.4 (C4'), 137.8 (C3'), 125.4 (C5'), 98.8 (C7), 67.6 (C5), 61.5 (C2), $60.9\left(\mathrm{OCH}_{2} \mathrm{CH}_{3}\right), 33.7$ (C4), $\left.14.7\left(\mathrm{OCH}_{2} \mathrm{CH}_{3}\right) ; \mathrm{m} / \mathrm{z}(\mathrm{ESI})^{-}\right) 339$ ([M-H]', 100\%) 
and $341\left([\mathrm{M}-\mathrm{H}]^{-}, 33 \%\right)$; HRMS (ESI $\left.{ }^{-}\right) \mathrm{m} / \mathrm{z}$ : [M-H] $]^{-}$Calcd for $\mathrm{C}_{14} \mathrm{H}_{12} \mathrm{O}_{4} \mathrm{~N}_{2} \mathrm{ClS} 339.0212$ and 341.0182; Found 339.0208 and 341.0177.

\section{(2R,5R)-1-Aza-2-(6-chloropyridin-3-yl)-5-methoxycarbonyl-6,8-dioxo-3-thiabicyclo[3.3.0]-octane,}

\section{5}

Yield (70 mg, 3\%); orange oil; $R_{\mathrm{f}}=0.21(\mathrm{MeOH}:$ EtOAc; $1: 6) ;[\alpha]_{\mathrm{D}}^{25}=-113.9(c=1.00, \mathrm{MeOH})$; $v_{\max } / \mathrm{cm}^{-1} 1583$ (s, C=C), 1695 (s, C=O); ${ }^{1} \mathrm{H}$ NMR (methanol- $d_{4}, 400 \mathrm{MHz}$ ): $\delta 8.48\left(\mathrm{~s}, 1 \mathrm{H}, \mathrm{H} 2^{\prime}\right), 7.95$ (d, $\left.1 \mathrm{H}, J=8.3 \mathrm{~Hz}, \mathrm{H} 4^{\prime}\right), 7.45\left(\mathrm{~d}, 1 \mathrm{H}, J=8.3 \mathrm{~Hz}, \mathrm{H} 5^{\prime}\right), 6.40(\mathrm{~s}, 1 \mathrm{H}, \mathrm{H} 2), 4.17-4.30(\mathrm{~m}, 2 \mathrm{H}, \mathrm{H} 7), 3.70(\mathrm{~s}$, $3 \mathrm{H}, \mathrm{CO}_{2} \mathrm{CH}_{3}$ ), $3.21-3.28$ (obscured, $\mathrm{H}_{\mathrm{B}}$ ), 3.03 (dd, $1 \mathrm{H}, \mathrm{J}=11.2,7.2 \mathrm{~Hz}, \mathrm{H} 4_{\mathrm{A}}$ ); ${ }^{13} \mathrm{C}$ NMR (methanol$d_{4}, 101 \mathrm{MHz}$ ): $\delta 194.6$ (C6), 180.0 (C8), $167.1\left(\mathrm{CO}_{2} \mathrm{CH}_{3}\right), 151.2\left(\mathrm{C}^{\prime}\right), 148.9\left(\mathrm{C}^{\prime}\right), 139.4$ (C4'), 139.1 (C3'), 125.2 (C5'), 70.4 (C5), 62.5 (C2), $59.5\left(\mathrm{CO}_{2} \mathrm{CH}_{3}\right), 50.3$ (C7), 34.8 (C4); m/z (ESI') 325 ([M-H]', 100\%) and $327\left([\mathrm{M}-\mathrm{H}]^{-}, 33 \%\right)$; HRMS $\left(\mathrm{ESI}^{+}\right) \mathrm{m} / \mathrm{z}:[\mathrm{M}+\mathrm{H}]^{+}$Calcd for $\mathrm{C}_{13} \mathrm{H}_{12} \mathrm{O}_{4} \mathrm{~N}_{2} \mathrm{ClS} 327.0201$ and 329.0171; Found 327.0203 and 329.0172.

\section{(2S,5R)-1-Aza-7-(4-chloro-2-methylphenylaminocarbonyl)-6-hydroxy-8-oxo-2-(pyridin-2-yl)-3-}

\section{thiabicyclo[3.3.0]oct-6-ene, 6a}

Yield (183 mg, 70\%); brown oil; $R_{\mathrm{f}}=0.34(\mathrm{MeOH}:$ EtOAc; $1: 6) ;[\alpha]_{\mathrm{D}}^{25}=-114.6\left(c=0.67, \mathrm{CHCl}_{3}\right)$; $v_{\max } / \mathrm{cm}^{-1} 1644$ (s, C=O), 1678 (s, C=O); $\left.{ }^{1} \mathrm{H} \mathrm{NMR} \mathrm{(CDCl} 3,400 \mathrm{MHz}\right): \delta 9.39$ (br. s, $\left.1 \mathrm{H}, \mathrm{NH}\right), 8.61$ (br. d, $\left.1 \mathrm{H}, H 6^{\prime}\right), 8.02$ (br. d, $\left.1 \mathrm{H}, H 6^{\prime \prime}\right), 7.72\left(\mathrm{t}, 1 \mathrm{H}, J=7.6 \mathrm{~Hz}, \mathrm{H} 4^{\prime}\right), 7.41$ (d, $1 \mathrm{H}, J=7.7 \mathrm{~Hz}, \mathrm{H} 3^{\prime}$ ), 7.19 (br. s, $3 \mathrm{H}, \mathrm{H} 3^{\prime \prime}, \mathrm{H} 5^{\prime \prime}$ and $\mathrm{H5}^{\prime}$ ), 6.35 (s, $1 \mathrm{H}, \mathrm{H} 2$ ), 5.11 (br. $\left.\mathrm{s}, 1 \mathrm{H}, \mathrm{H} 5\right), 3.45$ (dd, $1 \mathrm{H}, J=18.7,8.1 \mathrm{~Hz}, \mathrm{H} 4_{\mathrm{B}}$ ), $3.06-3.16\left(\mathrm{~m}, 1 \mathrm{H}, \mathrm{H}_{\mathrm{A}}\right), 2.33\left(\mathrm{~s}, 3 \mathrm{H}, \mathrm{CH}_{3}\right) ;{ }^{13} \mathrm{C} \mathrm{NMR}\left(\mathrm{CDCl}_{3}, 101 \mathrm{MHz}\right): \delta 188.0(\mathrm{C} 6), \mathrm{C} 8$ not shown, 163.8 (C9), 159.1 (C2'), 149.7 (C6'), 138.2 (C4'), 133.7 (C2'), 130.5 (C4"), 130.1 (C1", C3"), 126.8 (C5"), 123.2 (C3'), 122.8 (C6"), $120.2\left(\mathrm{C}^{\prime}\right), \mathrm{C} 7$ not shown, 67.1 (C5), 62.2 (C2), $32.4(\mathrm{C} 4), 17.8\left(\mathrm{CH}_{3}\right)$; $m / z$ (ESI $\left.^{-}\right) 400\left([\mathrm{M}-\mathrm{H}]^{-}, 100 \%\right)$ and $402\left([\mathrm{M}-\mathrm{H}]^{-}, 33 \%\right) ; \mathrm{HRMS}\left(\mathrm{ESI}^{+}\right) \mathrm{m} / z:[\mathrm{M}+\mathrm{H}]^{+}$Calcd for $\mathrm{C}_{19} \mathrm{H}_{17} \mathrm{O}_{3} \mathrm{~N}_{3} \mathrm{ClS} 402.0674$ and 404.0644; Found 402.0674 and 404.0643. 
(2S,5R)-1-Aza-2-(2-bromopyridin-4-yl)-7-(4-chloro-2-methylphenylaminocarbonyl)-6-hydroxy-8oxo-3-thiabicyclo[3.3.0]oct-6-ene, 6b

Yield (130 mg, 52\%); orange oil; $R_{\mathrm{f}}=0.30(100 \% \mathrm{EtOAc}) ;[\alpha]_{\mathrm{D}}^{25}=-151.6\left(c=1.01, \mathrm{CHCl}_{3}\right) ; v_{\max } / \mathrm{cm}^{-1}$ 1587 (s, C=C), 1634 (s, C=O), 1695 (s, C=O); ${ }^{1} \mathrm{H}$ NMR (CDCl, $400 \mathrm{MHz}$ ): $\delta 9.28$ (br. s, $\left.1 \mathrm{H}, \mathrm{NH}\right), 8.37$ $\left(\mathrm{d}, 1 \mathrm{H}, J=5.1 \mathrm{~Hz}, \mathrm{H} 6^{\prime}\right), 8.00\left(\mathrm{~d}, 1 \mathrm{H}, J=8.6 \mathrm{~Hz}, \mathrm{H6} 6^{\prime \prime}\right), 7.59\left(\mathrm{~s}, 1 \mathrm{H}, \mathrm{H} 3^{\prime}\right), 7.33\left(\mathrm{~d}, 1 \mathrm{H}, J=4.9 \mathrm{~Hz}, \mathrm{H} 5^{\prime}\right)$, $7.19\left(\right.$ app d, $2 \mathrm{H}, J=7.0 \mathrm{~Hz}, \mathrm{H3}^{\prime \prime}, \mathrm{H}^{\prime \prime}$ ), $6.18(\mathrm{~s}, 1 \mathrm{H}, \mathrm{H} 2$ ), 4.81 (app t, $1 \mathrm{H}, J=6.9 \mathrm{~Hz}, \mathrm{H} 5$ ), $3.29-3.34$ $(\mathrm{m}, 1 \mathrm{H}, \mathrm{H} 4 \mathrm{~B}), 3.10(\mathrm{dd}, 1 \mathrm{H}, J=11.2,8.3 \mathrm{~Hz}, \mathrm{H} 4 \mathrm{~A}), 2.33\left(\mathrm{~s}, 3 \mathrm{H}, \mathrm{CH}_{3}\right) ;{ }^{13} \mathrm{CNMR}\left(\mathrm{CDCl}_{3}, 101 \mathrm{MHz}\right): \delta$ 184.9 (C6), 172.3 (C8), 163.6 (C9), $151.9\left(\mathrm{C}^{\prime}\right), 150.6$ (C4'), 142.9 (C2'), 133.3 (C2'), 131.0 (C4"), 130.6 (C3"), 130.2 (C1"), 126.9 (C5”), 125.5 (C3'), 122.9 (C6"), 120.6 (C5'), 98.9 (C7), 66.5 (C5), $60.2(\mathrm{C} 2), 32.6(\mathrm{C} 4), 17.7\left(\mathrm{CH}_{3}\right) ; \mathrm{m} / \mathrm{z}\left(\mathrm{ESI}^{-}\right)$478, $\left.480\left([\mathrm{M}-\mathrm{H}]^{-}, 100 \%\right)\right)$ and $482\left([\mathrm{M}-\mathrm{H}]^{-}, 33 \%\right) ; \mathrm{HRMS}$ (ESI $\left.{ }^{-}\right) \mathrm{m} / \mathrm{z}$ : [M-H] $]^{-}$Calcd for $\mathrm{C}_{19} \mathrm{H}_{14} \mathrm{O}_{3} \mathrm{~N}_{3} \mathrm{BrClS}$ 477.9633, 479.9613 and 481.9583; Found 477.9636, 479.9612 and 481.9580.

(2S,5R)-1-Aza-2-(5-bromopyridin-2-yl)-7-(4-chloro-2-methylphenylaminocarbonyl)-6-hydroxy-8oxo-3-thiabicyclo[3.3.0]oct-6-ene, 6c

Yield (154 mg, 62\%); orange oil; $R_{\mathrm{f}}=0.39(100 \% \mathrm{EtOAc}) ;[\alpha]_{\mathrm{D}}^{25}=-142.1\left(c=0.63, \mathrm{CHCl}_{3}\right) ; v_{\max } / \mathrm{cm}^{-1}$ 1483 (s, C=C), 1587 (s, C=C), 1635 (s, C=O), 1693 (s, C=O); ${ }^{1} \mathrm{H}$ NMR (CDCl, $\left.400 \mathrm{MHz}\right): \delta 9.34$ (br. s, $1 \mathrm{H}, \mathrm{NH}), 8.65\left(\mathrm{~s}, 1 \mathrm{H}, \mathrm{H6^{ \prime }}\right), 8.03\left(\mathrm{~d}, 1 \mathrm{H}, J=9.2 \mathrm{~Hz}, \mathrm{H6^{ \prime \prime }}\right.$ ), $7.83\left(\mathrm{~d}, 1 \mathrm{H}, J=8.3 \mathrm{~Hz}, \mathrm{H} 4^{\prime}\right.$ ), 7.56 (br. s, 1H, $\mathrm{OH}$ ), $7.31\left(\mathrm{~d}, 1 \mathrm{H}, J=8.3 \mathrm{~Hz}, \mathrm{H} 3^{\prime}\right.$ ), 7.19 (br. s, 2H, H3"' $\mathrm{H}^{\prime \prime}$ ), 6.28 (s, 1H, H2), 5.08 (app t, $1 \mathrm{H}, J=7.6$ $\mathrm{Hz}, \mathrm{H} 5$ ), 3.44 (dd, $1 \mathrm{H}, J=10.8,7.5 \mathrm{~Hz}, \mathrm{H} 4_{\mathrm{B}}$ ), 3.10 (dd, $1 \mathrm{H}, J=10.6,8.5 \mathrm{~Hz}, \mathrm{H} 4_{\mathrm{A}}$ ), $2.33\left(\mathrm{~s}, 3 \mathrm{H}, \mathrm{CH}_{3}\right) ;{ }^{13} \mathrm{C}$ NMR (CDCl $3,101 \mathrm{MHz}): \delta 185.0$ (C6), 171.9 (C8), 163.7 (C9), 157.8 (C2'), 151.1 (C6'), 139.7 (C4'), 133.5 (C2"), 130.5 (C4"), 130.3 (C3"), 130.1 (C1"), 126.9 (C5"), 122.8 (C6"), 121.5 (C3'), 120.1 (C5'), 99.0 (C7), 67.0 (C5), 61.8 (C2), $32.3(\mathrm{C} 4), 17.7\left(\mathrm{CH}_{3}\right) ; \mathrm{m} / \mathrm{z}\left(\mathrm{ESI}^{-}\right) 478$ and $480\left([\mathrm{M}-\mathrm{H}]^{-}, 100 \%\right)$ and 482 
([M-H] $\left.]^{-}, 33 \%\right) ; H R M S\left(E S I^{-}\right) \mathrm{m} / z$ : [M-H] $]^{-}$Calcd for $\mathrm{C}_{19} \mathrm{H}_{14} \mathrm{O}_{3} \mathrm{~N}_{3} \mathrm{BrClS}$ 477.9633, 479.9613 and 481.9583; Found 477.9632, 479.9608 and 481.9575.

\section{(2S,5R)-1-Aza-7-(4-chloro-2-methylphenylaminocarbonyl)-2-(6-chloropyridin-3-yl)-6-hydroxy-8-} oxo-3-thiabicyclo[3.3.0]oct-6-ene, 6d

Yield (171 mg, 67\%); orange oil; $R_{\mathrm{f}}=0.31(100 \% \mathrm{EtOAc}) ;[\alpha]_{\mathrm{D}}^{25}=-145.4\left(c=1.01, \mathrm{CHCl}_{3}\right) ; v_{\max } / \mathrm{cm}^{-1}$ 1585 (s, C=C), 1633 (s, C=O), 1693 (s, C=O); ${ }^{1} \mathrm{H}$ NMR (CDCl, $400 \mathrm{MHz}$ ): $\delta 9.29$ (br. s, $\left.1 \mathrm{H}, \mathrm{NH}\right), 8.90$ (br. s, $1 \mathrm{H}, \mathrm{OH}), 8.52\left(\mathrm{~s}, 1 \mathrm{H}, \mathrm{H} 2^{\prime}\right), 8.00\left(\mathrm{~d}, 1 \mathrm{H}, J=8.9 \mathrm{~Hz}, \mathrm{H} 6^{\prime \prime}\right), 7.78\left(\mathrm{~d}, 1 \mathrm{H}, J=8.3, \mathrm{H} 4^{\prime}\right), 7.34(\mathrm{~d}, 1 \mathrm{H}, J$ $\left.=8.3 \mathrm{~Hz}, \mathrm{H} 5^{\prime}\right), 7.19\left(\operatorname{app} d, 2 \mathrm{H}, J=7.0 \mathrm{~Hz}, \mathrm{H} 3^{\prime \prime}, \mathrm{H}^{\prime \prime}\right), 6.24(\mathrm{~s}, 1 \mathrm{H}, \mathrm{H} 2), 4.82($ app t, $1 \mathrm{H}, J=7.4 \mathrm{~Hz}$, H5), $3.33(\mathrm{dd}, 1 \mathrm{H}, J=11.3,7.1 \mathrm{~Hz}, \mathrm{H} 4 \mathrm{~B}), 3.10\left(\mathrm{dd}, 1 \mathrm{H}, J=11.3,8.4 \mathrm{~Hz}, \mathrm{H} 4_{\mathrm{A}}\right), 2.33\left(\mathrm{~s}, 3 \mathrm{H}, \mathrm{CH}_{3}\right) ;{ }^{13} \mathrm{C}$ NMR ( $\left.\mathrm{CDCl}_{3}, 101 \mathrm{MHz}\right): \delta 184.7$ (C6), 172.3 (C8), 163.7 (C9), 151.7 (C2'), 148.3 (C6'), 137.6 (C4'), $134.8\left(\mathrm{C3}^{\prime}\right), 133.5$ (C2"), 130.7 (C4"), 130.5 (C3"), 130.3 (C1"), 127.0 (C5"), 124.5 (C5'), 123.0 (C6"), 99.2 (C7), 66.6 (C5), 59.5 (C2), 32.7 (C4), $17.8\left(\mathrm{CH}_{3}\right) ; \mathrm{m} / \mathrm{z}\left(\mathrm{ESI}^{-}\right) 434$ ([M-H]', 100\%) and 436 ([M-H]', 65\%); HRMS (ESI') m/z: [M-H] $]^{-}$Calcd for $\mathrm{C}_{19} \mathrm{H}_{14} \mathrm{O}_{3} \mathrm{~N}_{3} \mathrm{Cl}_{2} \mathrm{~S} 434.0138$ and 436.0109; Found 434.0134 and 436.0104 .

\section{(2S,5R)-1-Aza-7-(cyclohexylaminocarbonyl)-6-hydroxy-8-oxo-2-(pyridin-2-yl)-3-}

\section{thiabicyclo[3.3.0]oct-6-ene,7a}

Yield (96 mg, 41\%); orange oil; $R_{\mathrm{f}}=0.47(\mathrm{MeOH}:$ EtOAc; $1: 6) ;[\alpha]_{\mathrm{D}}^{25}=+116.9\left(c=1.00, \mathrm{CHCl}_{3}\right)$; $V_{\max } / \mathrm{cm}^{-1} 1557$ (s, C=C), 1620 (s, C=O), 1688 (s, C=O); ${ }^{1} \mathrm{H}$ NMR $\left(\mathrm{CDCl}_{3}, 400 \mathrm{MHz}\right): \delta$ (NH and OH obscured), 8.58 (d, $1 \mathrm{H}, J=4.2 \mathrm{~Hz}, \mathrm{H} 6^{\prime}$ ), 7.67 (app td, $\left.1 \mathrm{H}, J=7.7,1.7 \mathrm{~Hz}, \mathrm{H} 4^{\prime}\right), 7.38(\mathrm{~d}, 1 \mathrm{H}, J=7.8 \mathrm{~Hz}$, $\left.H 3^{\prime}\right), 7.20\left(\mathrm{dd}, 1 \mathrm{H}, J=7.0,5.2 \mathrm{~Hz}, \mathrm{H} 5^{\prime}\right), 6.33(\mathrm{~s}, 1 \mathrm{H}, \mathrm{H} 2), 4.84$ (br. $\left.\mathrm{s}, 1 \mathrm{H}, \mathrm{H} 5\right), 3.79-3.89$ (m, 1H, H10), 3.35 (dd, $1 \mathrm{H}, J=10.9,7.3 \mathrm{~Hz}, \mathrm{H}_{\mathrm{B}}$ ), 3.03 (dd, $\left.1 \mathrm{H}, J=10.9,8.4 \mathrm{~Hz}, \mathrm{H} 4_{\mathrm{A}}\right), 1.87-1.98(\mathrm{~m}, 2 \mathrm{H}, 2 \mathrm{x}$ $\mathrm{H} 11), 1.69-1.80(\mathrm{~m}, 2 \mathrm{H}, 2 \times \mathrm{H} 12), 1.56-1.65(\mathrm{~m}, 2 \mathrm{H}, 2 \times \mathrm{H} 13), 1.17-1.44(\mathrm{~m}, 2 \times \mathrm{H} 11,2 \times \mathrm{H} 12)$; ${ }^{13} \mathrm{C} \mathrm{NMR}\left(\mathrm{CDCl}_{3}, 101 \mathrm{MHz}\right): \delta$ (C8 and C6 not shown), 165.5 (C9), 159.8 (C2'), 149.9 (C6'), 137.1 
(C4'), 122.9 (C3'), 119.9 (C5'), 100.1 (C7), 68.3 (C5), 62.8 (C2), 46.0 (C10), 38.8 (C11), 32.8 (C4), 25.4 (C13), 24.6 (C12); m/z (ESI $) 358\left([\mathrm{M}-\mathrm{H}]^{-}, 100 \%\right) ; H R M S\left(E S I^{+}\right) \mathrm{m} / z:[\mathrm{M}+\mathrm{H}]^{+}$Calcd for $\mathrm{C}_{18} \mathrm{H}_{22} \mathrm{O}_{3} \mathrm{~N}_{3} \mathrm{~S} 360.1376$; Found 360.1378.

\section{(2S,5R)-1-Aza-2-(2-bromopyridin-4-yl)-7-(cyclohexylaminocarbonyl)-6-hydroxy-8-oxo-3-}

\section{thiabicyclo[3.3.0]oct-6-ene, 7b}

Yield (34 mg, 15\%); orange oil; $R_{\mathrm{f}}=0.65(\mathrm{MeOH}:$ EtOAc; $1: 9) ;[\alpha]_{\mathrm{D}}^{25}=-128.0\left(c=0.60, \mathrm{CHCl}_{3}\right)$; $v_{\max } / \mathrm{cm}^{-1} 1586(\mathrm{~s}, \mathrm{C}=\mathrm{C}), 1624(\mathrm{~s}, \mathrm{C}=0), 1691(\mathrm{~s}, \mathrm{C}=\mathrm{O}) ;{ }^{1} \mathrm{H}$ NMR $\left(\mathrm{CDCl}_{3}, 400 \mathrm{MHz}\right)$ : a $3.3: 1$ mixture of $\mathrm{AB} / \mathrm{CD}$ tautomers: $\delta 8.34\left(\mathrm{~d}, 1 \mathrm{H}, J=5.0 \mathrm{~Hz}, \mathrm{H} 6^{\prime}\right), 7.86$ (br. s, $1 \mathrm{H}, \mathrm{OH}$ ), $7.57\left(\mathrm{~s}, 1 \mathrm{H}, \mathrm{H} 3^{\prime}\right.$ ), 7.42 (br. s, $1 \mathrm{H}, \mathrm{NH}), 7.31\left(\mathrm{~d}, 1 \mathrm{H}, J=4.8 \mathrm{~Hz}, \mathrm{H} 5^{\prime}\right), 6.24(\mathrm{~s}, 1 \mathrm{H}, \mathrm{H} 2$ minor tautomer), $6.16(\mathrm{~s}, 1 \mathrm{H}, \mathrm{H} 2$ major tautomer), 4.73 (br. s, 1H, H5 minor tautomer), 4.61 (br. s, 1H, H5 major tautomer), $3.79-3.92$ (m, $1 \mathrm{H}, \mathrm{H} 10), 3.21-3.32\left(\mathrm{~m}, 1 \mathrm{H}, \mathrm{H} 4_{B}\right), 3.01-3.11\left(\mathrm{~m}, 1 \mathrm{H}, \mathrm{H} 4_{A}\right), 1.88-1.97(\mathrm{~m}, 2 \mathrm{H}, 2 \times \mathrm{H} 11), 1.71-$ $1.80(\mathrm{~m}, 2 \mathrm{H}, 2 \times \mathrm{H} 12), 1.55-1.68(\mathrm{~m}, 2 \mathrm{H}, 2 \times \mathrm{H} 13), 1.21-1.48(\mathrm{~m}, 4 \mathrm{H}, 2 \times \mathrm{H} 11,2 \times \mathrm{H} 12) ;{ }^{13} \mathrm{C}\left\{{ }^{1} \mathrm{H}\right\}$ NMR (CDCl $3,126 \mathrm{MHz}$ ): $\delta 191.2$ (C6 minor), 189.1 (C6 major), 178.4 (C8 minor), 172.8 (C8 major), 165.4 (C9), $152.6\left(C 6^{\prime}\right), 150.5\left(C 4^{\prime}\right), 142.8\left(C 2^{\prime}\right), 125.6$ (C3'), 120.7 (C5'), 95.8 (C7 minor), 93.8 (C7 major), 70.5 (C5 minor), 67.6 (C5 major), 61.2 (C2 minor), 60.6 (C2 major), 49.9 (C10 minor), 48.6 (C10 major), 32.8 (C4), 32.1 (C11), 25.3 (C13), 24.5 (C12); m/z (ESI-) 436 and 438 ([M-H]', 100\%); HRMS (ESI) $\mathrm{m} / \mathrm{z}$ : [M-H] $]^{-}$Calcd for $\mathrm{C}_{18} \mathrm{H}_{19} \mathrm{O}_{3} \mathrm{~N}_{3} \mathrm{BrS} 436.0336$ and 438.0316; Found 436.0336 and 438.0315.

(2S,5R)-1-Aza-2-(5-bromopyridin-2-yl)-7-(cyclohexylaminocarbonyl)-6-hydroxy-8-oxo-3thiabicyclo[3.3.0]oct-6-ene, 7c

Yield (71 mg, 31\%); yellow oil; $R_{\mathrm{f}}=0.81(\mathrm{MeOH}:$ EtOAc; $1: 6) ;[\alpha]_{\mathrm{D}}^{25}=-87.3\left(c=1.01, \mathrm{CHCl}_{3}\right)$; $v_{\max } / \mathrm{cm}^{-1} 1558$ (s, C=C), 1648 (s, C=O), 1690 (s, C=O); ${ }^{1} \mathrm{H}$ NMR ( $\left.\mathrm{CDCl}_{3}, 400 \mathrm{MHz}\right): \delta 9.96$ (br. s, $1 \mathrm{H}$, $\mathrm{NH}), 8.60\left(\mathrm{~s}, 1 \mathrm{H}, \mathrm{H} 6^{\prime}\right), 7.77\left(\mathrm{~d}, 1 \mathrm{H}, J=8.3 \mathrm{~Hz}, \mathrm{H} 4^{\prime}\right), 7.44$ (br. s, $\left.1 \mathrm{H}, \mathrm{OH}\right), 7.28\left(\mathrm{~d}, 1 \mathrm{H}, J=8.3 \mathrm{~Hz}, \mathrm{H} 3^{\prime}\right)$, 
6.25 (s, 1H, H2), 4.81 (br. s, 1H, H5), $3.72-3.91$ (m, 1H, H10), 3.32 (dd, $1 \mathrm{H}, J=10.9,7.4 \mathrm{~Hz}, \mathrm{H} 4$ в), $3.01(\mathrm{dd}, 1 \mathrm{H}, J=10.8,8.4 \mathrm{~Hz}, \mathrm{H} 4 \mathrm{~A}), 1.78-2.09(\mathrm{~m}, 2 \mathrm{H}, 2 \times \mathrm{H} 11), 1.63-1.78(\mathrm{~m}, 2 \mathrm{H}, 2 \times \mathrm{H} 12), 1.48$ $-1.65(\mathrm{~m}, 2 \mathrm{H}, 2 \times \mathrm{H} 13), 1.21-1.48(\mathrm{~m}, 4 \mathrm{H}, 2 \times \mathrm{H} 11,2 \times \mathrm{H} 12) ;{ }^{13} \mathrm{C} \mathrm{NMR}\left(\mathrm{CDCl}_{3}, 101 \mathrm{MHz}\right): \delta 188.5$ (C6), 172.3 (C8), 165.4 (C9), 158.4 (C2'), 150.8 (C6'), 139.5 (C4'), 121.3 (C3'), 119.7 (C5'), 107.3 (C7), 67.9 (C5), 62.2 (C2), 48.3 (C10), 32.7 (C4), 32.0 (C11), 25.3 (C13), 24.5 (C12); m/z (APCl ${ }^{+} 438$ and $\left.440\left([\mathrm{M}+\mathrm{H}]^{+}, 100 \%\right) ; \mathrm{HRMS}(\mathrm{APCl})^{+}\right) \mathrm{m} / \mathrm{z}:[\mathrm{M}+\mathrm{H}]^{+}$Calcd for $\mathrm{C}_{18} \mathrm{H}_{21} \mathrm{O}_{3} \mathrm{~N}_{3} \mathrm{BrS} 438.0482$ and 440.0461 ; Found 438.0477 and 440.0456.

(2S,5R)-1-Aza-7-(cyclohexylaminocarbonyl)-2-(6-chloropyridin-3-yl)-6-hydroxy-8-oxo-3thiabicyclo[3.3.0]oct-6-ene, 7d

Yield (55 mg, 24\%); yellow oil; $R_{\mathrm{f}}=0.62(\mathrm{MeOH}:$ EtOAc; $1: 6) ;[\alpha]_{\mathrm{D}}^{25}=-141.1\left(c=1.00, \mathrm{CHCl}_{3}\right)$;

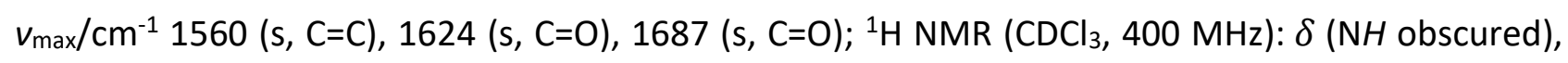
$8.48\left(\mathrm{~s}, 1 \mathrm{H}, \mathrm{H} 2^{\prime}\right), 7.75\left(\mathrm{~d}, 1 \mathrm{H}, J=8.3 \mathrm{~Hz}, \mathrm{H} 4^{\prime}\right), 7.30\left(\mathrm{~d}, 1 \mathrm{H}, J=8.3 \mathrm{~Hz}, \mathrm{H} 5^{\prime}\right), 6.89$ (br. s, $\left.1 \mathrm{H}, \mathrm{OH}\right), 6.24$ (s, 1H, H2), 4.59 (br. s, 1H, H5), $3.76-3.90$ (m, 1H, H10), 3.26 (dd, $1 \mathrm{H}, J=11.2,7.4 \mathrm{~Hz}, \mathrm{H} 4$ в), 3.05 $\left(\mathrm{dd}, 1 \mathrm{H}, J=11.2,8.2 \mathrm{~Hz}, \mathrm{H} 4_{\mathrm{A}}\right), 1.84-2.00(\mathrm{~m}, 2 \mathrm{H}, 2 \times \mathrm{H} 11), 1.69-1.80(\mathrm{~m}, 2 \mathrm{H}, 2 \times \mathrm{H} 12), 1.52-$ $1.71(\mathrm{~m}, 2 \mathrm{H}, 2 \times \mathrm{H} 13), 1.20-1.43(\mathrm{~m}, 4 \mathrm{H}, 2 \times \mathrm{H} 11,2 \times \mathrm{H} 12) ;{ }^{13} \mathrm{C} \mathrm{NMR}\left(\mathrm{CDCl}_{3}, 101 \mathrm{MHz}\right): \delta 188.7$ (C6), 173.3 (C8), 165.4 (C9), 151.3 (C2'), $148.1\left(\mathrm{C6}^{\prime}\right), 137.5$ (C4'), 135.3 (C3'), $124.2\left(\mathrm{C5}^{\prime}\right), 100.1$ (C7), 67.4 (C5), 59.9 (C2), 48.5 (C10), 32.7 (C4), 32.0 (C11), 25.3 (C13), 24.5 (C12); m/z (ESI') 392 ([M-H]', 100\%) and $394\left([\mathrm{M}-\mathrm{H}]^{-}, 33 \%\right)$; HRMS (ESI $) \mathrm{m} / \mathrm{z}:[\mathrm{M}-\mathrm{H}]^{-}$Calcd for $\mathrm{C}_{18} \mathrm{H}_{19} \mathrm{O}_{3} \mathrm{~N}_{3} \mathrm{ClS} 392.0841$ and 394.0812; Found 392.0843 and 394.0811.

\section{(2S,5R)-1-Aza-2-(2-bromopyridin-4-yl)-6-hydroxy-8-oxo-7-(tetrahydro-2H-pyran-4-} aminocarbonyl)-3-thiabicyclo[3.3.0]oct-6-ene, 8b

Yield (28 mg, 12\%); orange oil; $R_{\mathrm{f}}=0.44(\mathrm{MeOH}:$ EtOAc; $1: 6) ;[\alpha]_{\mathrm{D}}^{25}=-127.7\left(c=1.30, \mathrm{CHCl}_{3}\right)$; $v_{\max } / \mathrm{cm}^{-1} 1587$ (s, C=C), 1623 (s, C=O), 1648 (s, C=O), 1691 (s, C=O); ${ }^{1} \mathrm{H}$ NMR (CDCl, $\left.400 \mathrm{MHz}\right): \mathrm{a}$ 
3.3 : 1 mixture of $A B / C D$ tautomers: $\delta 9.29$ (br. s, $1 \mathrm{H}, \mathrm{NH}$ ), 8.53 (d, J=5.0 Hz, H6' minor), 8.35 (d, $1 \mathrm{H}, J=5.1 \mathrm{~Hz}, \mathrm{H} 6^{\prime}$ major), 8.07 (s, H3' minor), 7.83 (d, $J=5.0 \mathrm{~Hz}, \mathrm{H} 5^{\prime}$ minor), 7.57 (s, 1H, H3'), 7.41 (br. s, 1H, OH), 7.32 (d, 1H, J = $5.0 \mathrm{~Hz}, \mathrm{H} 5^{\prime}$ major), 6.20 (s, H2 minor), 6.14 (s, 1H, H2 major), 4.67 (br. s, 1H, H5 major), 4.39 (dd, $J=7.1,2.2 \mathrm{~Hz}, \mathrm{H} 5$ minor), $4.03-4.11(\mathrm{~m}, 1 \mathrm{H}, \mathrm{H} 10), 3.98(\mathrm{~d}, 2 \mathrm{H}, J=$ $11.3 \mathrm{~Hz}, 2 \times \mathrm{H} 12), 3.46-3.52(\mathrm{~m}, 2 \mathrm{H}, 2 \times \mathrm{H} 12), 3.27$ (dd, $1 \mathrm{H}, J=11.2,7.2 \mathrm{~Hz}, \mathrm{H} 4 \mathrm{~B}), 3.05(\mathrm{dd}, 1 \mathrm{H}, J=$ $\left.11.2,8.1 \mathrm{~Hz}, \mathrm{H}_{\mathrm{A}}\right), 1.92(\mathrm{~d}, 2 \mathrm{H}, J=11.2 \mathrm{~Hz}, 2 \mathrm{H} 11), 1.54-1.67(\mathrm{~m}, 2 \mathrm{H}, 2 \mathrm{H} 11) ;{ }^{13} \mathrm{C}\left\{{ }^{1} \mathrm{H}\right\} \mathrm{NMR}\left(\mathrm{CDCl}_{3}\right.$, $126 \mathrm{MHz}$ ): $\delta 193.0$ (C6 minor), 187.2 (C6 major), 176.9 (C8 minor), 172.5 (C8 major), 165.9 (C9 minor), 165.3 (C9 major), 152.4 (C6' minor), 151.0 (C6' major), 150.5 (C4' major), 150.1 (C4' minor), 142.8 (C2' major), 140.5 (C2' minor), 128.3 (C3' minor), 125.6 (C3' major), 122.4 (C5' minor), 120.7 (C5' major), 95.7 (C7 major), 83.9 (C7 minor), 67.0 (C5), 66.4 (C12), 60.4 (C2), 45.7 (C10), 32.7 (C4), $32.0(\mathrm{C} 11) ; \mathrm{m} / \mathrm{z}\left(\mathrm{ESI}^{+}\right) 440$ and $442\left([\mathrm{M}+\mathrm{H}]^{+}, 100 \%\right) ; \mathrm{HRMS}\left(\mathrm{ESI}^{-}\right) \mathrm{m} / z:[\mathrm{M}-\mathrm{H}]^{-}$Calcd for $\mathrm{C}_{17} \mathrm{H}_{17} \mathrm{O}_{4} \mathrm{~N}_{3} \mathrm{BrS} 438.0129$ and 440.0108; Found 438.0134 and 440.0111.

\section{(2S,5R)-1-Aza-2-(5-bromopyridin-2-yl)-6-hydroxy-8-oxo-7-(tetrahydro-2H-pyran-4-}

\section{aminocarbonyl)-3-thiabicyclo[3.3.0]oct-6-ene, 8c}

Yield (23 mg, 10\%); orange oil; $R_{\mathrm{f}}=0.50(\mathrm{MeOH}: \mathrm{EtOAc} ; 1: 6) ;[\alpha]_{\mathrm{D}}^{25}=-119.8\left(c=0.74, \mathrm{CHCl}_{3}\right)$; $v_{\max } / \mathrm{cm}^{-1} 1578(\mathrm{~s}, \mathrm{C}=\mathrm{C}), 1644(\mathrm{~s}, \mathrm{C}=\mathrm{O}), 1676(\mathrm{~s}, \mathrm{C}=\mathrm{O}) ;{ }^{1} \mathrm{H} \mathrm{NMR}\left(\mathrm{CDCl}_{3}, 400 \mathrm{MHz}\right)$ : a $3.4: 1$ mixture of AB/CD tautomers: $\delta$ ( $\mathrm{NH}$ and $\mathrm{OH}$ obscured), 8.63 (s, 1H, H6' minor), 8.61 (s, 1H, H6' major), 7.78 (d, $1 \mathrm{H}, J=8.3 \mathrm{~Hz}, \mathrm{H} 4^{\prime}$ major), 7.29 (d, 1H, J = $8.3 \mathrm{~Hz}, \mathrm{H} 3^{\prime}$ ), 6.30 (s, 1H, H2 major), 6.25 (s, 1H, H2 minor), $4.90($ app t, $1 \mathrm{H}, J=7.6 \mathrm{~Hz}, \mathrm{H} 5), 4.37($ app q, $1 \mathrm{H}, J=7.0 \mathrm{~Hz}, \mathrm{H} 10), 3.90-4.02(\mathrm{~m}, 2 \mathrm{H}, 2 \times \mathrm{H} 12), 3.42$ - $3.54(\mathrm{~m}, 2 \mathrm{H}, 2 \times \mathrm{H} 12), 3.37\left(\mathrm{dd}, 1 \mathrm{H}, J=10.9,7.3 \mathrm{~Hz}, \mathrm{H} 4_{B}\right), 2.97-3.07\left(\mathrm{~m}, 1 \mathrm{H}, \mathrm{H} 4_{A}\right), 1.82-1.98(\mathrm{~m}$, 2H, 2x H11), $1.52-1.68$ (m, 2H, 2x H11); ${ }^{13} \mathrm{C}\left\{{ }^{1} \mathrm{H}\right\} \mathrm{NMR}\left(\mathrm{CDCl}_{3}, 126 \mathrm{MHz}\right): \delta 177.9$ (C6), 173.0 (C8), 167.9 (C9), 159.1 (C2' minor), 158.2 (C2' major), 150.9 (C6' major), 150.8 (C6' minor), 139.7 (C4'), 121.6 (C3' minor), 121.4 (C3' major), 120.7 (C5' minor), 119.9 (C5' major), 96.2 (C7), 66.9, 66.7, 66.5, 66.1 (C5 and C12, major and minor tautomers), 62.4 (C2), 45.9 (C10), 32.8 (C4), 32.1 (C11); 
$m / z\left(\mathrm{ESI}^{+}\right) 440$ and $442\left([\mathrm{M}+\mathrm{H}]^{+}, 100 \%\right) ; \mathrm{HRMS}\left(\mathrm{ESI}^{-}\right) \mathrm{m} / \mathrm{z}:[\mathrm{M}-\mathrm{H}]^{-}$Calcd for $\mathrm{C}_{17} \mathrm{H}_{17} \mathrm{O}_{4} \mathrm{~N}_{3} \mathrm{BrS} 438.0129$ and 440.0108; Found 438.0132 and 440.0110.

\section{(2S,5R)-7-(Adamantylaminocarbonyl)-1-aza-6-hydroxy-8-oxo-2-(pyridin-2-yl)-3-}

\section{thiabicyclo[3.3.0]oct-6-ene, 9a}

Yield (118 mg, 44\%); brown oil; $R_{\mathrm{f}}=0.70(\mathrm{MeOH}:$ EtOAc; $1: 6) ;[\alpha]_{\mathrm{D}}^{25}=-21.6\left(c=1.00, \mathrm{CHCl}_{3}\right)$; $v_{\max } / \mathrm{cm}^{-1} 1560$ (s, C=C), 1633 (s, C=O), $1684(\mathrm{C}=\mathrm{O}) ;{ }^{1} \mathrm{H} \mathrm{NMR}\left(\mathrm{CDCl}_{3}, 400 \mathrm{MHz}\right): \delta$ (OH obscured), 10.15 (br. s, $1 \mathrm{H}, \mathrm{NH}$ ), 8.58 (d, $1 \mathrm{H}, J=4.3 \mathrm{~Hz}, \mathrm{H} 6^{\prime}$ ), 7.67 (app td, $1 \mathrm{H}, J=7.7,1.7 \mathrm{~Hz}, \mathrm{H} 4^{\prime}$ ), 7.38 (d, $1 \mathrm{H}$, $\left.J=7.8 \mathrm{~Hz}, \mathrm{H} 3^{\prime}\right), 7.19$ (dd, $\left.1 \mathrm{H}, J=7.7,5.2 \mathrm{~Hz}, \mathrm{H} 5^{\prime}\right), 6.31$ (s, 1H, H2), 4.84 (br. s, $1 \mathrm{H}, \mathrm{H} 5$ ), 3.33 (dd, 1H, $\left.J=10.9,7.3 \mathrm{~Hz}, \mathrm{H} 4_{\mathrm{B}}\right), 3.01$ (dd, $1 \mathrm{H}, J=10.9,8.5 \mathrm{~Hz}, \mathrm{H}_{\mathrm{A}}$ ), 2.11 (br. s, 3H, Adamantyl-CH), 2.05 (br. s, 6H, Adamantyl- $\mathrm{CH}_{2}$ ), 1.69 (br. s, 6H, Adamantyl- $\left.\left.\mathrm{CH}_{2}\right) ;{ }^{13} \mathrm{C} \mathrm{NMR} \mathrm{(CDCl}, 101 \mathrm{MHz}\right): \delta 188.8$ (C6), C8 not shown, 166.3 (C9), 159.8 (C2'), $149.8\left(\mathrm{C6}^{\prime}\right), 137.1$ (C4'), 122.9 (C3'), $119.8\left(\mathrm{C5}^{\prime}\right), \mathrm{C} 7$ not shown, 68.0 (C5), 62.7 (C2), 53.3 (Adamantyl-C), 41.7 (Adamantyl- $\mathrm{CH}_{2}$ ), 36.1 (Adamantyl- $\mathrm{CH}_{2}$ ), 32.7 (C4), 29.4 (Adamantyl-CH); m/z (ESI) $410\left([\mathrm{M}-\mathrm{H}]^{-}\right.$, 100\%); HRMS $\left(\mathrm{ESI}^{+}\right) \mathrm{m} / \mathrm{z}:[\mathrm{M}+\mathrm{H}]^{+}$Calcd for $\mathrm{C}_{22} \mathrm{H}_{26} \mathrm{O}_{3} \mathrm{~N}_{3} \mathrm{~S}$ 412.1689; Found 412.1691.

\section{(2S,5R)-7-(Adamantylaminocarbonyl)-1-aza-2-(2-bromopyridin-4-yl)-6-hydroxy-8-oxo-3-}

\section{thiabicyclo[3.3.0]oct-6-ene, 9b}

Yield (84 mg, 33\%); orange oil; $R_{\mathrm{f}}=0.62(\mathrm{MeOH}:$ EtOAc; $1: 9) ;[\alpha]_{\mathrm{D}}^{25}=-135.6\left(c=1.01, \mathrm{CHCl}_{3}\right)$; $v_{\max } / \mathrm{cm}^{-1} 1584(\mathrm{~s}, \mathrm{C}=\mathrm{C}), 1648(\mathrm{~s}, \mathrm{C}=\mathrm{O}), 1688(\mathrm{~s}, \mathrm{C}=\mathrm{O}) ;{ }^{1} \mathrm{H} \mathrm{NMR}\left(\mathrm{CDCl}_{3}, 400 \mathrm{MHz}\right): \delta$ (OH obscured), 8.99 (br. s, $1 \mathrm{H}, \mathrm{NH}), 8.32$ (d, $\left.1 \mathrm{H}, J=5.1 \mathrm{~Hz}, \mathrm{H} 6^{\prime}\right), 7.55$ (s, $\left.1 \mathrm{H}, \mathrm{H} 3^{\prime}\right), 7.30\left(\mathrm{~d}, 1 \mathrm{H}, J=5.2 \mathrm{~Hz}, \mathrm{H} 5^{\prime}\right), 6.17$ (s, $1 \mathrm{H}, \mathrm{H} 2$ ), 4.48 (br. s, $1 \mathrm{H}, \mathrm{H} 5), 3.24$ (dd, $1 \mathrm{H}, J=11.2,7.4 \mathrm{~Hz}, \mathrm{H} 4 \mathrm{~B}), 3.04$ (dd, $1 \mathrm{H}, J=11.2,8.1 \mathrm{~Hz}$, H4 ${ }_{A}$ ), 2.12 (br. s, 3H, Adamantyl-CH), 2.05 (br. s, 6H, Adamantyl-CH2), 1.69 (br. s, 6H, Adamantyl$\left.\mathrm{CH}_{2}\right) ;{ }^{13} \mathrm{CNMR}\left(\mathrm{CDCl}_{3}, 101 \mathrm{MHz}\right): \delta 190.0$ (C6), C8 not shown, 166.2 (C9), $152.8\left(\mathrm{C6}^{\prime}\right), 150.4$ (C4'), 142.8 (C2'), 125.5 (C3'), 120.7 (C5'), 100.1 (C7), 68.4 (C5), 60.8 (C2), 53.9 (Adamantyl-C), 41.7 
(Adamantyl- $\mathrm{CH}_{2}$ ), 36.1 (Adamantyl- $\mathrm{CH}_{2}$ ), 32.9 (C4), 29.4 (Adamantyl-CH); $\mathrm{m} / \mathrm{z}(\mathrm{ESI})^{-}$) 488 and 490 ([M-H], 100\%); HRMS (ESI') m/z: [M-H]- Calcd for $\mathrm{C}_{22} \mathrm{H}_{23} \mathrm{O}_{3} \mathrm{~N}_{3} \mathrm{BrS} 488.0649$ and 490.0629; Found 488.0652 and 490.0629.

\section{(2S,5R)-7-(Adamantylaminocarbonyl)-1-aza-2-(5-bromopyridin-2-yl)-6-hydroxy-8-oxo-3-}

\section{thiabicyclo[3.3.0]oct-6-ene, 9c}

Yield (97 mg, 38\%); brown oil; $R_{\mathrm{f}}=0.56(\mathrm{MeOH}:$ EtOAc; $1: 9) ;[\alpha]_{\mathrm{D}}^{25}=-97.0\left(c=0.53, \mathrm{CHCl}_{3}\right)$; $v_{\max } / \mathrm{cm}^{-1} 1559(\mathrm{~s}, \mathrm{C}=\mathrm{C}), 1648(\mathrm{~s}, \mathrm{C}=\mathrm{O}), 1687(\mathrm{~s}, \mathrm{C}=\mathrm{O}) ;{ }^{1} \mathrm{H}$ NMR $\left(\mathrm{CDCl}_{3}, 400 \mathrm{MHz}\right)$ : a $2.3: 1$ mixture of AB/CD tautomers: $\delta 8.63\left(\mathrm{~s}, 1 \mathrm{H}, \mathrm{H} 6^{\prime}\right), 7.80\left(\mathrm{dd}, 1 \mathrm{H}, J=8.3,2.2 \mathrm{~Hz}, \mathrm{H} 4^{\prime}\right), 7.30\left(\mathrm{~d}, 1 \mathrm{H}, J=8.3 \mathrm{~Hz}, \mathrm{H} 3^{\prime}\right)$, 6.53 (br. s, 2H, OH and $\mathrm{NH}$ ), 6.33 (s, H2 minor), 6.25 (s, 1H, H2 major), 4.81 (t, $1 \mathrm{H}, J=7.8 \mathrm{~Hz}, \mathrm{H} 5$ major), 4.57 (t, $J=7.9 \mathrm{~Hz}, \mathrm{H} 5$ minor), 3.33 (app dt, $1 \mathrm{H}, J=11.0,6.8 \mathrm{~Hz}, \mathrm{H} 4 \mathrm{~B}), 2.99-3.07$ (m, 1H, H4A), 2.12 (br. s, 3H, Adamantyl-CH), 2.05 (br. s, 6H, Adamantyl- $\mathrm{CH}_{2}$ ), 1.70 (br. s, 6H, Adamantyl$\left.\mathrm{CH}_{2}\right) ;{ }^{13} \mathrm{C} \mathrm{NMR}\left(\mathrm{CDCl}_{3}, 101 \mathrm{MHz}\right): \delta 189.2$ (C6 major), 172.5 (C8 major), 166.2 (C9 major), 158.4 (C2'), 150.9 (C6'), 140.9 (C4' minor), 139.6 (C4' major), 121.3 (C3'), 119.8 (C5'), 94.3 (C7 major), 68.1 (C5 major), 66.3 (C5 minor), 62.9 (C2 minor), 62.2 (C2 major), 53.4 (Adamantyl-C), 44.3 (Adamantyl- $\mathrm{CH}_{2}$ minor), 41.7 (Adamantyl- $\mathrm{CH}_{2}$ major), 36.2 (Adamantyl- $\mathrm{CH}_{2}$ major), 36.0 (Adamantyl- $\mathrm{CH}_{2}$ minor), 33.0 ( $\mathrm{C} 4$ minor), 32.6 (C4 major), 29.8 (Adamantyl-CH minor), 29.4 (Adamantyl-CH major); $m / z\left(\mathrm{ESI}^{+}\right) 490$ and $492\left([\mathrm{M}+\mathrm{H}]^{+}, 100 \%\right) ; \mathrm{HRMS}(\mathrm{ESI})^{+} \mathrm{m} / \mathrm{z}:[\mathrm{M}+\mathrm{H}]^{+}$Calcd for $\mathrm{C}_{22} \mathrm{H}_{25} \mathrm{O}_{3} \mathrm{~N}_{3} \mathrm{BrS} 490.0795$ and $492.0774 ;$ Found 490.0795 and 492.0773.

\section{(2S,5R)-7-(Adamantylaminocarbonyl)-1-aza-2-(6-chloropyridin-3-yl)-6-hydroxy-8-oxo-3-}

\section{thiabicyclo[3.3.0]oct-6-ene, 9d}

Yield (92 mg, 35\%); orange oil; $R_{\mathrm{f}}=0.70(\mathrm{MeOH}:$ EtOAc; $1: 9) ;[\alpha]_{\mathrm{D}}^{25}=-90.5\left(c=1.10, \mathrm{CHCl}_{3}\right)$; $v_{\max } / \mathrm{cm}^{-1} 1562(\mathrm{~s}, \mathrm{C}=\mathrm{C}), 1627(\mathrm{~s}, \mathrm{C}=\mathrm{O}), 1686(\mathrm{~s}, \mathrm{C}=\mathrm{O}) ;{ }^{1} \mathrm{H} \mathrm{NMR}\left(\mathrm{CDCl}_{3}, 500 \mathrm{MHz}\right)$ : a 3.2 : 1 mixture of $\mathrm{AB} / \mathrm{CD}$ tautomers: $\delta$ (NH obscured), $8.49\left(\mathrm{~s}, 1 \mathrm{H}, \mathrm{H} 2^{\prime}\right), 7.75\left(\mathrm{~d}, 1 \mathrm{H}, J=8.3, \mathrm{H} 5^{\prime}\right.$ major), 7.39 (br. s, 1H, 
$\mathrm{OH}), 7.32\left(\mathrm{~d}, 1 \mathrm{H}, J=8.3 \mathrm{~Hz}, \mathrm{H} 4^{\prime}\right.$ major tautomer), 6.31 (s, H2 minor), 6.23 (s, 1H, H2 major), 4.59 (app t, $1 \mathrm{H}, J=7.7 \mathrm{~Hz}, \mathrm{H5}$ ), $3.26\left(\mathrm{dd}, 1 \mathrm{H}, J=11.2,7.2 \mathrm{~Hz}, \mathrm{H} 4_{\mathrm{B}}\right.$ ), 3.05 (dd, $1 \mathrm{H}, J=11.1,8.2 \mathrm{~Hz}, \mathrm{H} 4_{\mathrm{A}}$ ), 2.13 (br. s, 3H, Adamantyl-CH), 2.06 (br. s, 6H, Adamantyl- $\mathrm{CH}_{2}$ ), 1.70 (br. s, 6H, Adamantyl- $\mathrm{CH}_{2}$ ); ${ }^{13} \mathrm{C}\left\{{ }^{1} \mathrm{H}\right\}$ NMR $\left(\mathrm{CDCl}_{3}, 126 \mathrm{MHz}\right.$ ): $\delta 191.1$ (C6 minor), 189.5 (C6 major), 173.0 (C8 major), 167.9 (C9 minor), 166.2 (C9 major), $151.3\left(\mathrm{C2}^{\prime}\right), 148.2\left(\mathrm{C} 6^{\prime}\right), 137.5$ (C4'), 135.3 (C3'), 124.2 (C5'), 93.9 (C7 major), 67.7 (C5), 59.9 (C2), 53.7 (Adamantyl-C), 41.7 (Adamantyl- $\mathrm{CH}_{2}$ ), 36.2 (Adamantyl- $\mathrm{CH}_{2}$ major), 36.0 (Adamantyl- $\mathrm{CH}_{2}$ minor), 32.8, 32.1 ( $\mathrm{C} 4$ major and minor tautomers), 29.8 (AdamantylCH minor), 29.4 (Adamantyl-CH major); $m / z$ (ESI') 444 ([M-H] $\left.]^{-}, 100 \%\right)$ and 446 ([M-H] ; 33\%); HRMS $\left(\mathrm{ESI}^{-}\right) \mathrm{m} / \mathrm{z}$ : [M-H] $]^{-}$Calcd for $\mathrm{C}_{22} \mathrm{H}_{23} \mathrm{O}_{3} \mathrm{~N}_{3} \mathrm{ClS} 444.1154$ and 446.1125; Found 444.1157 and 446.1125.

\section{Supporting Information}

The Supporting Information is available free of charge on the ACS Publications website at DOI: 10.1021/acs.joc.xxxx. Supporting Tables; ${ }^{1} \mathrm{H}$ and ${ }^{13} \mathrm{C}$ NMR spectra; calculated energies (PDF).

\section{References}

1. Tommasi, R.; Brown, D. G.; Walkup, G. K.; Manchester, J. I.; Miller, A. A. ESKAPEing the labyrinth of antibacterial discovery. Nat. Rev. Drug Discovery 2015, 14, 529-542.

2. Laxminarayan, R.; Duse, A.; Wattal, C.; Zaidi, A. K. M.; Wertheim, H. F. L.; Sumpradit, N.; Vlieghe, E.; Hara, G. L.; Gould, I. M.; Goossens, H.; Greko, C.; So, A. D.; Bigdeli, M.; Tomson, G.; Woodhouse, W.; Ombaka, E.; Arturo Quizhpe Peralta; Qamar, F. N.; Mir, F.; Kariuki, S.; Bhutta, Z. q. A.; Coates, A.; Bergstrom, R.; Wright, G. D.; Brown, E. D.; Cars, O. Antibiotic resistance-the need for global solutions. Lancet 2014, 13, 1057-98.

3. Howard, S. J.; Catchpole, M.; Watson, J.; Davies, S. C. Antibiotic resistance: global response needed. Lancet Infect. Dis. 2013, 13, 1001-1003.

4. Butler, M. S.; Blaskovich, M. A.; Cooper, M. A. Antibiotics in the clinical pipeline in 2013. J Antibiot 2013, 66 (10), 571-591.

5. McCoy, L. S.; Xie, Y.; Tor, Y. Antibiotics that target protein synthesis. Wiley Interdisciplinary Reviews: RNA 2011, 2, 209-232.

6. Brown, D. G.; Lister, T.; May-Dracka, T. L. New natural products as new leads for antibacterial drug discovery. Biorg. Med. Chem. Lett. 2014, 24, 413-418.

7. Cragg, G.; Newman, D. Natural products and drug discovery and development: A history of success and continuing promise for the future. Planta Medica 2014, 80, 750-750.

8. Genilloud, $\mathrm{O}$. The re-emerging role of microbial natural products in antibiotic discovery. Antonie van Leeuwenhoek 2014, 106, 173-188. 
9. Rossiter, S. E.; Fletcher, M. H.; Wuest, W. W. Natural Products as Platforms to Overcome Antibiotic Resistance. Chem. Rev. 2017, 117, 12415-12474.

10. Petermichl, M.; Schobert, R., 3-Acyltetramic acids: A decades-long approach to a fascinating natural product family. Synlett 2017, 28, 654-663.

11. Zhang, G. T.; Zhang, W. J.; Saha, S.; Zhang, C. S. Recent Advances in Discovery, Biosynthesis and Genome Mining of Medicinally Relevant Polycyclic Tetramate Macrolactams. Curr. Top. Med. Chem. 2016, 16, 1727-1739.

12. Schobert, R.; Schlenk, A. Tetramic and tetronic acids: An update on new derivatives and biological aspects. Bioorg. Med. Chem. 2008, 16, 4203-4221.

13. Royles, B. J. L. Naturally-occurring tetramic acids - Structure, isolation, and synthesis. Chem. Rev. 1995, 95, 1981-2001.

14. Winterer, M.; Kempf, K.; Schobert, R. Synthesis of an Isomer of the Decalinoyltetramic Acid Methiosetin by a Stereocontrolled IMDA Reaction of a Metal-Chelated 3-Trienoyltetramate. J. Org. Chem. 2016, 81, 7336-7341.

15. Bruckner, S.; Haase, R. G.; Schobert, R. A Synthetic Route to -Hydroxytyrosine-Derived Tetramic Acids: Total Synthesis of the Fungal Metabolite F-14329. Chemistry - Eur. J. 2017, 23, 5692-5695.

16. Lovmo, K.; Dütz, S.; Harras, M.; Haase, R. G.; Milius, W.; Schobert, R. A short synthesis of 3-enoyltetramic acids employing a new acyl ylide conjugate of Meldrum's acid. Tetrahedron Lett. 2017, 58, 4796-4798.

17. Dandawate, P.; Padhye, S.; Schobert, R.; Biersack, B. Discovery of natural products with metal-binding properties as promising antibacterial agents. Expert Opin. Drug Discovery 2019, 14, 563-576.

18. Khan, M. K.; Wang, D.; Moloney, M. G. Functionalised Nitrogen Heterocycles and the Search for New Antibacterials and Bioactives. Synthesis 2020, 52, 1602-1616.

19. Panduwawala, T. D.; Iqbal, S.; Thompson, A. L.; Genov, M.; Pretsch, A.; Pretsch, D.; Liu, S.; Ebright, R. H.; Howells, A.; Maxwell, A.; Moloney, M. G. Functionalised bicyclic tetramates derived from cysteine as antibacterial agents. Org. Biomol. Chem. 2019, 17, 5615-5632.

20. Panduwawala, T. D.; Iqbal, S.; Tirfoin, R.; Moloney, M. G. Chemoselectivity and stereoselectivity of cyclisation pathways leading to bicyclic tetramates controlled by ring-chain tautomerisation in thiazolidines. Org. Biomol. Chem. 2016, 14, 4464-4478.

21. Hansch, C. B., J. P.; Leo, A. Hydrophobicity and Central Nervous System Agents: On the Principle of Minimal Hydrophobicity in Drug Design. J. Pharm. Sci. 1987, 76, 663-687.

22. Seebach, D.; Sting, A. R.; Hoffmann, M. Self-regeneration of stereocenters (SRS) Applications, limitations, and abandonment of a synthetic principle Angew. Chem., Int. Ed. Engl. 1996, 35, 2708-2748.

23. Jeanguenat, A.; Seebach, D. Stereoselective chain elongation at C-3 of cysteine through 2,3-dihydrothiazoles, without racemization. Preparation of 2-amino-5-hydroxy-3mercaptoalkanoic acid derivatives. J. Chem. Soc., Perkin Trans. 1 1991, 2291-2298.

24. Nagasaka, T.; Imai, T. Synthesis of Chiral Pyrrolidine Derivatives from (S)-Pyroglutamic Acid. I : 7-Substituted (2R, 5S)-2-Aryl-1-aza-3-oxabicyclo[3.3.0]octan-8-ones, 7-Substituted (2R, 5S)-2Aryl-1-aza-3-oxabicyclo[3.3.0]oct-6-en-8-ones and 3-Substituted (S)-5-(Hydroxymethyl)-2pyrrolidinones. Chem. Pharm. Bull. 1995, 43, 1081-1088.

25. Nagasaka, T.; Imai, T. A New Approach to Chiral 5,5-Disubstituted 2-Pyrrolidinones form (S)-Pyroglutamic Acid. Heterocycles 1995, 41, 1927-1930.

26. Claridge, T. D. W. High Resolution NMR Techniques in Organic Chemistry. 2nd ed.; Elsevier:. 2009. 
27. Andrews, M. D.; Brewster, A. G.; Crapnell, K. M.; Ibbett, A. J.; Jones, T.; Moloney, M. G.; Prout, K.; Watkin, D. Regioselective Dieckmann cyclisations leading to enantiopure highly functionalised tetramic acid derivatives. J. Chem. Soc., Perkin Trans. 1 1998, 223-235.

28. Jeong, Y.-C.; Moloney, M. G. Synthesis of and Tautomerism in 3-Acyltetramic Acids. J. Org. Chem. 2011, 76, 1342-1354.

29. Jeong, Y.-C.; Anwar, M.; Moloney, M. G.; Bikadi, Z.; Hazai, E. Natural product inspired antibacterial tetramic acid libraries with dual enzyme target activity. Chem. Sci. 2013, 4, 1008-1015. 30. O'Shea, R.; Moser, H. E. Physicochemical Properties of Antibacterial Compounds: Implications for Drug Discovery. J. Med. Chem. 2008, 51, 2871-2878.

Graphical abstract<smiles>[R10]NC(=O)C1=C(O)C2CSC(CC)N2C1=O</smiles> 